\title{
Ficus (Moraceae) da Serra da Mantiqueira, Brasil'
}

\author{
Ficus (Moraceae) from Serra da Mantiqueira, Brazil
}

\author{
Gisela Pelissari $^{2,3}$ \& Sergio Romaniuc Neto ${ }^{2}$
}

\begin{abstract}
Resumo
A Serra da Mantiqueira, localizada na Região Sudeste do Brasil, encontra-se entre os biomas Mata Atlântica e Cerrado, se estendendo pelos estados de São Paulo, Minas Gerais, Espírito Santo e Rio de Janeiro. Sua maior porção está no estado de Minas Gerais e a menor no Espírito Santo, na Serra do Caparaó. Ficus L. é o maior gênero da família Moraceae, com aproximadamente 800 espécies distribuídas na região tropical, incluindo espécies arbustivas, arbóreas, hemiepífitas e trepadeiras. As características mais marcantes do gênero são a inflorescência do tipo sicônio e a polinização por vespas. Para este estudo foram examinados materiais depositados em coleções científicas, além de coletas e observações das populações na natureza. Foram encontradas 25 espécies de Ficus, sendo 17 nativas e oito exóticas. São apresentadas descrições, observações sobre fenologia, distribuição geográfica, conservação, comentários taxonômicos e ilustrações. São descritas e ilustradas nesse trabalho as espécies nativas, dentre as quais seis encontram-se em perigo, devido à fragmentação do habitat e interferência antrópica.
\end{abstract}

Palavras-chave: conservação, subg. Pharmacosycea, subg. Urostigma, Sudeste, taxonomia.

\begin{abstract}
Serra da Mantiqueira is a mountain chain located in southeastern Brazil. It is located between the Atlantic Forest and Cerrado biomes, extending to four states in the region, with its major portion in the state of Minas Gerais and the minor one within Espírito Santo State, in Serra do Caparaó. Ficus L. is the largest genus of the family Moraceae, with approximately 800 species distributed in tropical regions, including shrubs, trees, hemiepiphytes and vines. The most striking features are the syconium inflorescence and pollination by wasps. For this study we examined materials deposited in scientific collections, as well as field trips, and observations of populations in nature. We found 25 species of Ficus, being 17 native and eight exotic. Descriptions, comments on phenology and geographic distribution, conservation, taxonomic comments and illustrations are presented. Native species are described here, of which six are considered endangered due to habitat fragmentation and anthropogenic interference.
\end{abstract}

Key words: conservation, subgenus Pharmacosycea, subgenus Urostigma, Southeast, taxonomy.

\section{Introdução}

Ficus L. é o maior gênero de Moraceae, com aproximadamente 800 espécies e distribuição tropical, subtropical, raramente em regiões temperadas. Destas, 100-120 espécies ocorrem na Região Neotropical. No Brasil, são reconhecidas 76 espécies nativas, distribuídas em dois subgêneros: Pharmacosycea (Miq.) Miq. e Urostigma (Gasp.) Miq. (Romaniuc Neto et al. 2012). Caracterizam-se principalmente pelo hábito arbóreo ou hemiepifítico, presença de látex leitoso em todas as partes da planta, estípulas terminais bem desenvolvidas, folhas com glândulas no pecíolo ou na base da lâmina e inflorescências denominadas sicônios, que abrigam numerosas flores estaminadas e pistiladas circundadas por bractéolas.

Figueiras e vespas polinizadoras possuem uma forte relação mutualística, apresentando alto grau de especificidade. Segundo estudos moleculares (Rønsted et al. 2005; LopezVaamonde et al. 2009) a origem dessa associação se deu há cerca de 60-70 milhões de anos. As figueiras são elementos-chave de muitas florestas tropicais, uma vez que uma grande variedade de animais, incluindo mamíferos,

\footnotetext{
${ }^{1}$ Parte da dissertação de Mestrado apresentada pela primeira autora.

${ }^{2}$ Instituto de Botânica - IBt, Núcleo de Pesquisa da Curadoria do Herbário SP, C.P. 68041, 04045-972, São Paulo, SP, Brasil.

${ }^{3}$ Autor para correspondência: pelissari.gi@gmail.com
} 
aves e até peixes, se alimentam de seus frutos sendo responsáveis pela dispersão das sementes e, dessa forma, auxiliam o equilíbrio biológico das florestas (Carauta 1989; Mendonça-Souza 2006; Shanahan et al. 2001). Embora cada figo contenha um grande número de sementes, permitindo uma alta dispersão, a conservação das espécies de Ficus exige um processo sofisticado para que uma população estável possa sobreviver de forma ideal (Carauta \& Diaz 2002a).

A região da Serra da Mantiqueira, embora rica em sua flora, ainda não é suficientemente conhecida para assegurar um desenvolvimento capaz de conservar sua riqueza florística. Está localizada entre os biomas Mata Atlântica e Cerrado, consideradas regiões de grande biodiversidade, sendo incluídas na lista das 34 áreas prioritárias para a conservação da biodiversidade do globo, os hotspots (Mittermeier et al. 1999; Myers et al. 2000; Klink \& Machado 2005). Levando-se em conta o avanço na perda da biodiversidade desses biomas apontado por diversos autores (Kurtz \& Araújo 2000; Tabarelli et al. 2005), é urgente o conhecimento da diversidade existente nas áreas naturais remanescentes, entre elas a Serra da Mantiqueira.

Diante da diversidade de Ficus, pelas peculiaridades do ambiente da Serra da Mantiqueira, pelo quadro de degradação encontrado na área e, pela falta de um trabalho de flora que sintetize e facilite o conhecimento desse táxon nessa região, esse trabalho objetivou descrever as espécies e esclarecer os problemas morfológicos e taxonômicos do gênero, além de reconhecer a distribuição geográfica, o habitat e o estado de conservação das espécies de Ficus na Serra da Mantiqueira.

\section{Material e Métodos}

A Serra da Mantiqueira é uma cadeia de montanhas localizada na Região Sudeste do Brasil. Não há uma delimitação política ou geográfica exata da Serra até o momento e a maioria dos autores diverge sobre seus limites. Neste trabalho, propomos uma delimitação (Fig. 1) a partir de Machado-Filho et al. (1983), incluindo os limites apresentados por CETEC (1983) e Várzea (1942), acrescido das áreas mencionadas como parte da Serra por Colabardini (2003), Lima (2008) e Garcia Junior (2011). Desta forma, a região como descrita acima será denominada, neste trabalho, de Mantiqueira.
Foram realizadas viagens de coleta entre dezembro de 2010 e outubro de 2011, priorizando localidades na Mantiqueira subamostradas, detectado a partir do estudo das coleções em herbários. Todo o material coletado foi processado de acordo com os métodos usuais em taxonomia (Fidalgo \& Bononi 1989; Mori et al. 1989) e depositado no herbário do Instituto de Botânica de São Paulo (SP). Os materiais dos herbários visitados (BHCB, CESJ, ESA, GUA, GFJP, HRCB, HXBH, IAC, INPA, PAMG, PMSP, R, RB, SP, SPF, SPSF, UEC, VIC) (Thiers 2012) serviram de base para a análise do material de Ficus para a região da Mantiqueira. Os caracteres morfológicos seguem as terminologias apresentadas por Lawrence (1951), Radford et al. (1974), Hickey \& King (2000) e Mello-Filho et al. (2001). Todo o material selecionado encontrase fértil, com sicônios em distintos estágios de desenvolvimento. Foi considerada apenas a variação morfológica observada nos exemplares provenientes da área de estudo. Apenas as espécies nativas foram descritas. Os comentários sobre distribuição geográfica das espécies foram

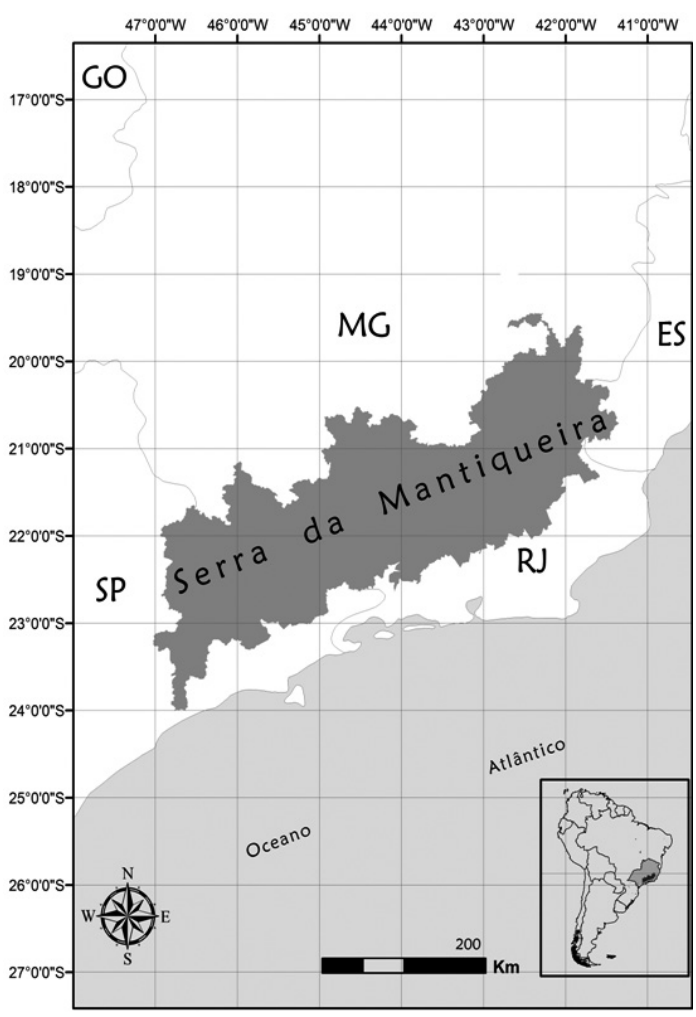

Figura 1 - Mapa da área de estudo Figure 1 - Map of study area 
realizados com base em dados obtidos na literatura e a partir das etiquetas de herbário, bem como através dos dados de coleta. Para a discussão da ocorrência das espécies foi adotado o sistema de classificação da vegetação proposto por Veloso et al. (1991) além de dados sobre vegetação encontrados em CETEC (1983) e MachadoFilho et al. (1983). Foi verificada a ocorrência das espécies em unidades de conservação na Mantiqueira, além de áreas particulares. As categorias de conservação das espécies para a Mantiqueira foram estabelecidas de acordo com os critérios da IUCN (apud Carauta \& Silva 1996), atualizados por IUCN (2011).

\section{Resultados e Discussão}

Ficus está representado na Mantiqueira por 17 espécies nativas e oito exóticas. Dentre as formações vegetacionais, a floresta ombrófila densa apresentou oito espécies, sendo F. pulchella Schott exclusiva dessa formação. Dentre as 16 espécies encontradas na floresta estacional semidecidual, nove são exclusivas desse tipo vegetacional ( $F$. castellviana Dugand, F. clusiifolia Schott, F. gomelleira Kunth, F. guaranitica Chodat, F. hirsuta Schott, F. lagoensis C.C.Berg \& Carauta, F. mariae C.C.Berg, Emygdio \& Carauta, F. obtusifolia Kunth e F. obtusiuscula (Miq.) Miq.). Floresta ombrófila mista e cerrado apresentam duas espécies cada. Ficus luschnathiana (Miq.) Miq. foi a única espécie encontrada em todas as formações vegetacionais. Além disso, de acordo com as categorias propostas pela IUCN (apud Carauta \& Silva 1996), atualizados por IUCN (2011), quatro espécies encontram-se na categoria "Vulnerável" (VU), uma "Em perigo" (EN) e uma está "Criticamente em perigo" (CR).

Ficus L., Sp. Pl. 1059. 1753.

Árvores ou hemiepífitas, monóicas; látex leitoso, branco a creme, ralo ou espesso; ramos castanho-acinzentados a castanho-avermelhados, glabros a tomentosos, indumento de tricomas alvos, ferrugíneos a avermelhados. Estípulas terminais completamente amplexicaules, caducas, raro persistentes, verdes a avermelhadas ou castanho-amareladas a vináceas, quando secas; faces ventral e dorsal glabra a pubescente. Folhas simples, inteiras, alternas-espiraladas, pecioladas; glândulas acropeciolares ou baselaminares. Lâminas elípticas, oblongas, obovadas ou ovadas, ápice acuminado, agudo, arredondado ou retuso, base cuneada, aguda, obtusa, truncada, arredondada, retusa, cordada a subcordada, margem inteira; cartáceas ou coriáceas, glabras ou pubescentes, macias ou escabras; nervação broquidódroma, nervuras na face abaxial proeminentes ou planas; pecíolo com epiderme persistente ou esfoliada. Sicônios com anisostilia, axilares, solitários ou aos pares, sésseis a pedunculados, globosos, oblongos ou piriformes, lisos ou verrucosos, verdes a verdeamarelados, verdes a violáceos na maturação, máculas brancas, creme, alvo-esverdeadas, amareladas castanho-escuro ou vináceas, glabros ou pubescentes; ostíolo plano, proeminente, crateriforme, circular a triangular; orobrácteas externas 2-7, imbricadas; epibrácteas 2-3, faces ventral e dorsal glabras a pubescentes; bractéolas numerosas, hialinas, alvas. Flores estaminadas sésseis a pediceladas, tépalas $2-5$, hialinas, livres ou adnatas na base, cuculadas, alvas, alvo-amareladas, alaranjadas ou rosadas, estames 1-2, anteras rimosas, 2-tecas, dorsifixas; flores pistiladas, sésseis a pediceladas, tépalas 3-5, hialinas, livres ou levemente adnatas na base, cuculadas, alvas, alvo-amareladas, alaranjadas ou rosadas, ovário súpero, 1-locular, 1-ovular, estilete 1, inteiro, lateral, estigma bífido, plumoso ou liso, decurrente ou reto. Drupas globosas a ovais, exocarpo membranáceo. Sementes 1, alvo-amareladas a alaranjadas, endosperma crustáceo.

Ficus compreende ca. 800 espécies, predominantemente tropicais (Berg \& Villavicencio 2004; Carauta \& Diaz 2002a). $\mathrm{Na}$ região da Mantiqueira foram encontradas 25 espécies, sendo oito exóticas ( $F$. aspera G.Forst., F. auriculata Lour., F. benjamina L., F. carica L., F. elastica Roxb., F. lyrata Warb., F. microcarpa L.f. e F. pumila L.) e 17 nativas. Dentre as nativas, 14 estão incluídas na seção Americana do subgênero Urostigma (F. arpazusa Casar., F. castellviana, F. clusiifolia, $F$. eximia Schott, F. gomelleira, F. guaranitica, F. hirsuta, F. lagoensis, F. luschnathiana (Miq.) Miq., F. mariae, F. mexiae Standl., F. obtusifolia, $F$. organensis (Miq.) Miq. e F. trigona L.f.) e três na seção Pharmacosycea do subgênero Pharmacosycea (F. adhatodifolia Schott, F. obtusiuscula e F. pulchella Schott). 


\section{Chave para identificação das espécies de Ficus da Mantiqueira}

1. Sicônios solitários.

2. Pecíolos 2-7 cm compr., epiderme do pecíolo persistente; ostíolo proeminente 1. F. adhatodifolia

2'. Pecíolos 1-1,5 cm compr., epiderme do pecíolo esfoliada; ostíolo plano 16. F. pulchella

1'. Sicônios aos pares.

3. Ostíolo crateriforme.

4. Ostíolo triangular

17. F. trigona

4'. Ostíolo circular.

5. Estípulas glabras; lâminas de ápice acuminado; 6-9 pares de nervuras secundárias .....

2. F. arpazusa

5'. Estípulas hirsutas; lâminas de ápice agudo a levemente cuspidado; 11-14 pares de nervuras secundárias

11. F. mariae

3'. Ostíolo plano a proeminente.

6. Folhas pubescentes.

7. Lâminas $2,5-5 \mathrm{~cm}$ compr., base aguda a arredondada

8. F. hirsuta

7'. Lâminas 6-25 cm compr., base truncada ou cordada.

8. Base da lâmina truncada; sicônios sésseis

9. F. lagoensis

8'. Base da lâmina cordada; sicônios pedunculados.

9. Folhas, estípulas e sicônios com tricomas vilosos; ostíolo sem anel circular; pedúnculos 1-4 mm compr. 3. F. castellviana

9'. Folhas, estípulas e sicônios com tricomas tomentosos; ostíolo com anel circular; pedúnculos 6-13 $\mathrm{mm}$ compr. 6. F. gomelleira

6'. Folhas glabras.

10. Sicônios piriformes a oblongos.

11. Lâminas oblongas, ápice acuminado, base cordada; sicônios piriformes, ostíolo plano

7. F. guaranitica

11'. Lâminas obovadas, ápice arredondado, base aguda a cuneada; sicônios oblongos, ostíolo proeminente

13. F. obtusifolia

10’. Sicônios globosos.

12. Sicônios sésseis.

13. Estípulas caducas; lâminas elípticas a oblongas, ápice agudo a acuminado, base aguda a obtusa; ostíolo sem anel circular 10. F. luschnathiana

13'. Estípulas persistentes; lâminas obovadas a oblanceoladas, ápice arredondado, base arredondada a hastado-cordada; ostíolo com anel circular 12. F. mexiae

12'. Sicônios pedunculados.

14. Lâminas obovadas, ápice e base arredondados 4. F. clusiifolia

14'. Lâminas elípticas a oblongas, ápice agudo, acuminado a cuspidado, base aguda, cordada a truncada.

15. Estípulas $27-45 \mathrm{~mm}$ compr.; estames 2

14. F. obtusiuscula

15'. Estípulas até $25 \mathrm{~mm}$ compr.; estame 1.

16. Lâminas com ápice acuminado a cuspidado, base cordada, subcordada a truncada; sicônios com máculas cremes, ostíolo proeminente ....

5. F. eximia

16'. Lâminas com ápice e base agudos; sicônios com máculas vináceas, ostíolo plano 15. F. organensis

1. Ficus adhatodifolia Schott in Sprengel, Syst. Veg., ed. 16. v. 4 (2, App.): 409. $1827 . \quad$ Fig. 2a-f

Árvores 8-25 m alt.; látex branco, espesso; ramos 3-7 mm diâm., castanho-acinzentados, glabros. Estípulas 1,5-5 cm compr., caducas, verde-claro, castanho-esverdeadas quando secas, glabras em ambas as faces. Lâminas elípticas a oblongas, 6,5-26,5 × 4,5$14 \mathrm{~cm}$, cartáceas a coriáceas, ápice agudo a levemente acuminado, base aguda a levemente truncada, face adaxial glabra a pubérula, tricomas alvo-esverdeados, macia a escabra, face abaxial pubérula, tricomas alvo-esverdeados, macia a escabra; 11-16 pares de 


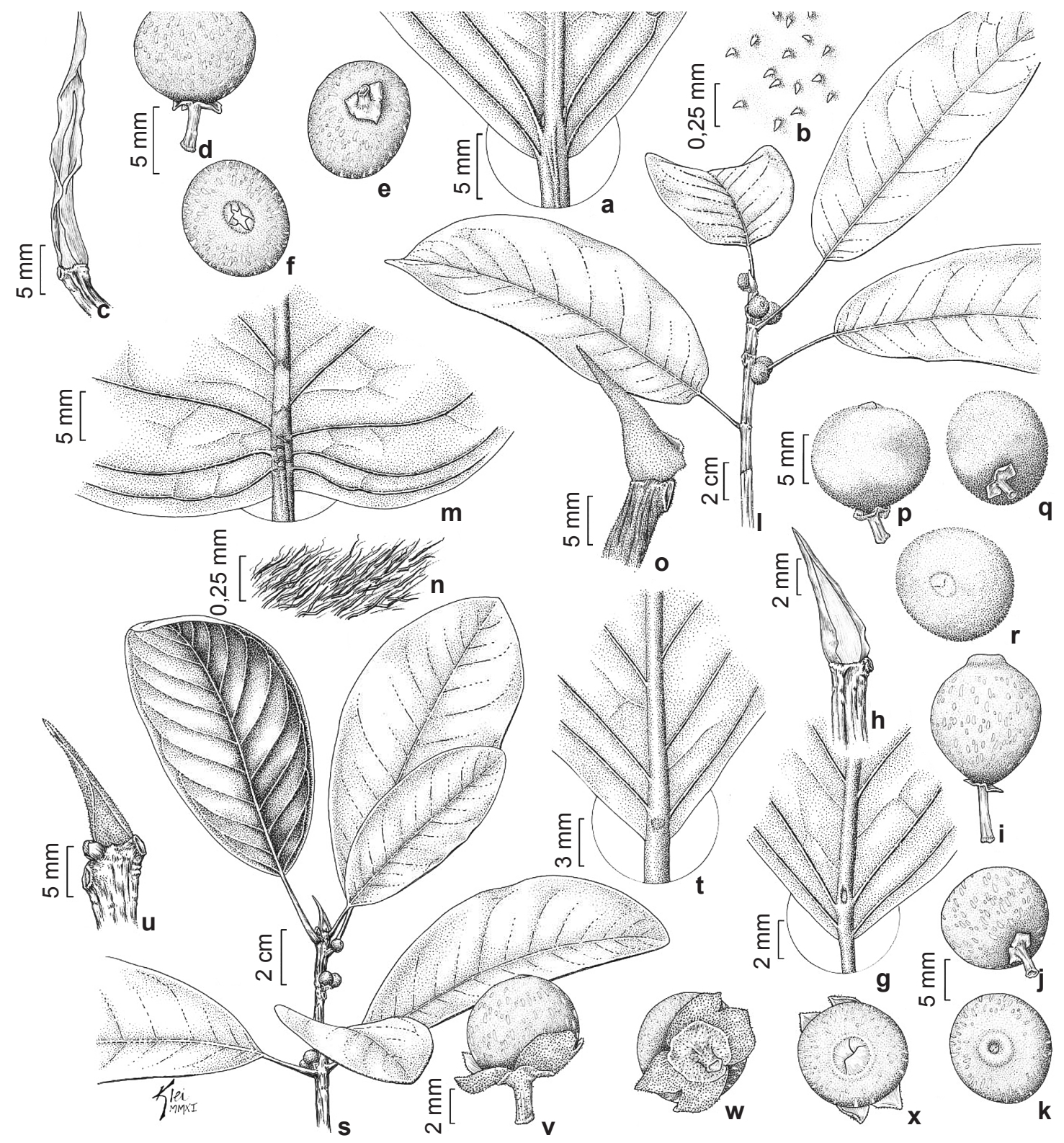

Figura 2 - a-f. F. adhatodifolia - a. base da lâmina foliar e par de glândulas baselaminares; b. indumento de tricomas escabros; c. estípula terminal no ramo; d. sicônio; e. vista basal do sicônio e epibrácteas; $f$. vista apical do sicônio, ostíolo e orobrácteas. g-k. F. arpazusa - g. base da lâmina foliar e glândula acropeciolar; h. estípula terminal no ramo; i. sicônio; j. visão basal do sicônio e epibrácteas; k. visão apical do sicônio, ostíolo e orobrácteas. 1-r. F. castellviana -1. ramo com folhas, estípula e sicônios; m. base da lâmina foliar e glândula acropeciolar; $n$. indumento da face abaxial da lâmina; o. estípula terminal no ramo; p. sicônio; q. visão basal do sicônio e epibrácteas; r. visão apical do sicônio, ostíolo e orobrácteas. s-x. F. clusiifolia - s. ramo com folhas, estípula e sicônios; t. base da lâmina foliar e glândula acropeciolar; u. estípula terminal no ramo; v. sicônio; w. visão basal do sicônio e epibrácteas; x. visão apical do sicônio, ostíolo e orobrácteas (a-f Pelissari 205; g-k Pelissari 186; 1-r Salino 414; s-x Pelissari 206). Figure 2 - a-f. F. adhatodifolia - a. base of the leaf and a pair of baselaminar glands; b. indument of scabrous trichomes; $\mathrm{c}$. terminal stipule on the twig; d. syconium; e. syconium basal view and epibracts; f. syconium apical view and orobracts. g-k. F. arpazusa - g. base of the leaf and acropetiolar gland; $\mathrm{h}$. terminal stipule on the twig; i. syconium; $\mathrm{j}$. syconium basal view and epibracts; $\mathrm{k}$. syconium apical view and orobracts. 1-r. F. castellviana -1 . twig with leaves, stipule and syconiums; $\mathrm{m}$. base of the leaf and acropetiolar gland; $\mathrm{n}$. indument in the abaxial surface; o. terminal stipule on the twig; p. syconium; q. syconium basal view and epibracts; $r$. syconium apical view and orobracts. s-x. F. clusiffolia - s. twig with leaves, stipule and syconiums; $t$. base of the leaf and acropetiolar gland; $u$. terminal stipule on the twig; $v$. syconium; $w$. syconium basal view and epibracts; $\mathrm{x}$. syconium apical view and orobracts (a-f Pelissari 205; $\mathrm{g}-\mathrm{k}$ Pelissari 186; 1-r Salino 414; s-x Pelissari 206). 
nervuras secundárias, levemente proeminentes na face abaxial; pecíolos 2-7 cm compr., glabros, epiderme persistente, par de glândulas baselaminares. Sicônios solitários, globosos, 1,5-2,7 cm diâm., lisos, glabros a pubérulos, tricomas alvo-esverdeados, macios a levemente escabros, verdes, castanho-escuros quando secos, máculas alvo-esverdeadas; pedúnculos 5-14 mm compr., glabros a pubérulos, tricomas alvoesverdeados; ostíolo proeminente, circular, 2-3 mm diâm.; orobrácteas externas 5-7; 3 epibrácteas, face ventral glabra, face dorsal glabra a pubérula, tricomas alvo-esverdeados. Flores estaminadas pediceladas: 5 tépalas, livres, alvas a rosadas, 2 estames; flores pistiladas: 5 tépalas, livres, alvas a rosadas, estigma liso, reto. Drupas ovais. Sementes alvo-amareladas. Material selecionado: ESPÍRITO SANTO: Dores do Rio Preto, Fazenda Cachoeira Alegre, 13.IX.2000, E.A. Costa 73 (RB). Três Estados, 12.X.2000, E.A. Costa 84 (RB). MINAS GERAIS: Carangola, Serra do Papagaio, I.1997, L.S. Leoni 3585 (GFJP, GUA). Dores do Turvo, 15.X.2001, J.P.D. Heleno 133 (GFJP). Olaria, Estrada Rio Preto, 10.XI.2003, F.R.G. Salimena \& P.H. Nobre 1111 (CESJ). Viçosa, 19.I.1931, Y. Mexia 4740 (VIC); Campus da UFV, 14.XII.2010, G. Pelissari et al. 189 (SP). RIO DE JANEIRO: Itatiaia, Distrito de Penedo, 17.II 2011, G. Pelissari et al. 204 (SP). SÃO PAULO: Monte Alegre do Sul, Bairro do Lambedor, 23.VII.1949, fr. M. Kuhlmann \& E. Kühn 1830 (SP). Pindamonhangaba, Fazenda São Sebastião do Ribeirão Grande, 18.VII.1999, S.A. Nicolau et al. 1753 (SP). São Paulo, Parque Estadual do Jaraguá, Trilha do Mauro, 4.XII.2007, F.M. Souza et al. 1031 (SPSF). Serra Negra, 22.XI.1991, F. Barros \& S.A.C. Chiea 2351 (SP).

Ficus adhatodifolia pode ser confundida com F. insipida quando em estado vegetativo. Entretanto, a arquitetura foliar dos materiais tipo de ambas as espécies, com base no trabalho de Ash et al. (1999), se diferem quanto às nervuras secundárias que em $F$. insipida são intramarginais, ou seja, as nervuras secundárias terminam paralelas a uma nervura marginal, o que não ocorre em $F$. adathodifolia, onde as nervuras são arqueadas, não apresentando uma nervura marginal. Esta característica, aliada a distribuição geográfica dos táxons proposta (Berg \& Villavicencio 2004) onde, F. adathodifolia se distribui principalmente no leste do Brasil, do Ceará a Argentina e Bolívia, passando por Goiás, Distrito Federal a Mato Grosso, enquanto $F$. insipida ocorre na região amazônica desde a bacia amazônica até a América Central, permitem considerar ambas as espécies.

Seus nomes populares são figueira branca, figueira de barranco, figueira vermífuga.

Tem como habitat a floresta ombrófila densa submontana e montana, floresta estacional semidecidual submontana e montana, floresta ombrófila mista e mata ciliar. Ficus adathodifolia ocorre em locais sombreados, em altitudes que variam de 390 a $1000 \mathrm{~m}$. Apesar de ter poucos registros em unidades de conservação é uma espécie de ampla distribuição na Mantiqueira. Espécie considerada em "Menor Preocupação", LC.

\section{Ficus arpazusa Casar., Nov. Stirp. Bras. 15.} 1842

Fig. 2g-k

Árvores ou hemiepífitas 4-10 m alt.; látex branco, ralo; ramos 3-5 mm diâm., castanhos, glabros. Estípulas 4-16 mm compr., caducas, vináceas, glabras em ambas as faces. Lâminas elípticas, 4,5-13 $\times 2,5-6,5 \mathrm{~cm}$, cartáceas a coriáceas, ápice acuminado, base cuneada, obtusa a arredondada, glabra em ambas as faces; 6-9 pares de nervuras secundárias, planas na face abaxial; pecíolos $1-4,5 \mathrm{~cm}$ compr., glabros, epiderme persistente, glândula acropeciolar. Sicônios aos pares, globosos, 1-1,7 cm diâm., lisos, glabros, macios, verdes, castanhos quando secos, máculas alvo-esverdeadas; pedúnculos 5-10 mm compr., glabros; ostíolo crateriforme, circular, 3-5 mm diâm.; 3 orobrácteas externas; 2 epibrácteas, glabra em ambas as faces. Flores estaminadas pediceladas: 2-3 tépalas, livres, alvo-alaranjadas quando secas, 1 estame; flores pistiladas: 2-3 tépalas, livres ou adnatas na base, alvo-alaranjadas, estigma plumoso, decurrente ou reto. Drupas ovais. Sementes alvo-amareladas.

Material selecionado: MINAS GERAIS: Baependi, Toca dos Urubus, 1.III.2005, F.M. Ferreira 858 (CESJ, HUEFS). Barroso, mata do Baú, 5.IV.2003, L.C.S. Assis \& M.S. Magalhães 785 (MBM, SPF). Carangola, Belvedere, 1.IX.1990, L.S. Leoni (GUA 37914). Caratinga, Estação Biológica de Caratinga, 18.I.1985, P.M. Andrade \& M.A. Lopes 603 (BHCB). Descoberto, Reserva Biológica Represa do Grama, 24.I.2001, R.M. Castro et al. 76 (CESJ, RB). Itamarati de Minas, Mineração de Alumínio - CBA, I.1998, L.V. Costa (BHCB 16597). Juiz de Fora, Reserva Biológica Municipal Santa Cândida, XII.2005, P.O. Garcia \& A.O. Cordeiro (CESJ 47129). Lima Duarte, Serra Negra, 26.X.2008, J.H.C. Ribeiro et al. 46 (CESJ). São Tomé das Letras, 1.VII.1987, H.F. Leitão-Filho et al. 19386 (UEC). Viçosa, Sítio Bonsucesso, mata do Seu Nico, 14.XII.2010, G. Pelissari et al. 186 (SP). RIO DE JANEIRO: Itatiaia, Penedo, Avenida 3 cachoeiras, 23.III.2002, P.P. Souza 146 (R, RB). SÃO PAULO: Atibaia, Fazenda Grota Funda, 16.XI.1987, J.A.A. Meira Neto et al. 21287 (UEC, VIC).

Ficus arpasuza é frequentemente confundido com quatro binômios: F. citrifolia Casar., F. eximia Schott, F. guaranitica Chodat e F. pertusa L.f. Carauta (1989) aceita as quatro espécies, considerando $F$. arpazusa como um dos sinônimos 
de F. citrifolia. Berg \& Villavicencio (2004) tratam Ficus guaranitica como sinônimo de F. citrifolia e $F$. arpazusa como sinônimo de $F$. pertusa. As características morfológicas dos materiais estudados da Mantiqueira correspondem ao tipo e a descrição de F. arpazusa Casar. Aceitamos como válidos os quatro binômios, sendo três deles ocorrentes na área estudada: F. arpazusa apresentando sicônio globoso com ostíolo marcadamente crateriforme, $F$. eximia com sicônio globoso e ostíolo proeminente e $F$. guaranitica, que apresenta sicônio piriforme e ostíolo plano a levemente proeminente.

Seu nome popular é mata pau.

Tem como habitat a floresta ombrófila densa submontana, montana e alto-montana e floresta estacional semidecidual submontana e montana. A espécie pode ser encontrada crescendo em fissuras de rochas e em pleno sol, em altitudes que variam de 340 a $920 \mathrm{~m}$. Possui registros em unidades de conservação, particulares e em áreas não protegidas, além de possuir ampla distribuição na Mantiqueira. Espécie considerada em “Menor Preocupação", LC.

\section{Ficus castellviana Dugand, Caldasia 1(4): 33. 1942. \\ Fig. 21-r}

Árvores ou hemiepífitas 3-8 m alt.; látex creme a branco, ralo; ramos jovens 3-8 mm diâm., avermelhados, pubescentes, tricomas vilosos, avermelhados. Estípulas 1-1,5 cm compr., caducas, tomentosas em ambas as faces, tricomas avermelhados. Lâminas oblongas, 11-25 × 4,5-11,5 cm, coriáceas, ápice acuminado, base cordada a subcordada, raramente arredondada; face adaxial pubescente, macia, face abaxial pubescente, tricomas avermelhados, macia; 12-16 pares de nervuras secundárias, proeminentes na face abaxial; pecíolos 3-7 cm compr., pubescentes, tricomas avermelhados, epiderme persistente, glândula acropeciolar. Sicônios aos pares, globosos, 8-11 mm diâm., lisos, pubescentes, tricomas avermelhados, macios, castanho-avermelhados quando secos, máculas creme; pedúnculos 1-4 mm compr., pubescentes, tricomas avermelhados; ostíolo plano, circular, anel circular ausente, $2-4$ mm diâm.; 2 orobrácteas externas; 2 epibrácteas, face ventral glabra a pubescente, tricomas avermelhados, face dorsal pubescente, tricomas avermelhados. Flores estaminadas pediceladas: 3 tépalas, adnatas na base, alvo-avermelhadas, 1 estame; flores pistiladas: 3 tépalas, adnatas na base, alvoavermelhadas, estigma plumoso, reto. Drupas ovais. Sementes amareladas.

Material selecionado: MINAS GERAIS: Caratinga, Fazenda Macedônia/Cenibra, 22.XI.1991, P.I.S. Braga et al. (RB 380447). Descoberto, Reserva Biológica da Represa do Grama, 2.II.2002, L.D. Meireles et al. (GUA 48387). Muriaé, margens do rio Glória, A. Salino 4114 (BHCB, VIC). Paula Cândido, Sítio das Palmeiras, 23.X.2007, P.P. Souza 207 (VIC). Viçosa, Porto Firme, 30.VIII.1986, A.L. Pinheiro (GUA 39072).

Ficus castellviana é facilmente reconhecida pela presença de tricomas avermelhados nos ramos, folhas, estípulas e sicônios. Berg \& Villavicencio (2004) sugerem que $F$. castellviana se assemelha à $F$. citrifolia, diferenciando-as pela presença de tricomas avermelhados em todas as partes da planta em $F$. castellviana .

Tem como habitat a floresta estacional semidecidual. Ficus castellviana pode ser encontrada próxima a cursos d'água, em mata ciliar, em altitudes que variam de 210 a $740 \mathrm{~m}$. Ocorre apenas em Minas Gerais, onde foi verificada a presença em apenas uma unidade de conservação. Os demais registros são de áreas particulares e locais sobre ação antrópica. Espécie "Próxima à Ameaçada", NT.

4. Ficus clusiifolia Schott in Sprengel, Syst. Veg., ed. 16.4 (2, App.): $409.1827 . \quad$ Fig. 2s-x

Árvores 4-10 m alt.; látex branco, espesso; ramos 4-6 mm diâm., castanho-acinzentados, glabros. Estípulas 14-17 mm compr., caducas, verdes, glabras em ambas as faces. Lâminas obovadas, 4-12,5 × 2,5-7 cm compr., coriáceas, ápice arredondado, base arredondada; glabra em ambas as faces, macia; 11-14 pares de nervuras secundárias, planas na face abaxial; pecíolos 1-3 cm compr., glabros, epiderme persistente, glândula acropeciolar. Sicônios aos pares, globosos, 5-7 mm diâm., lisos, glabros, macios, amarelos, máculas brancas; pedúnculos 1-2 mm compr., glabros a pubérulos, tricomas alvos; ostíolo plano, ca. 2 mm diâm.; 2 orobrácteas externas; epibrácteas 2 , bipartindo-se ao amadurecer, glabra em ambas as faces. Flores estaminadas pediceladas: 2 tépalas, livres ou adnatas na base, alvo-amareladas, 1 estame; flores pistiladas: 2-3 tépalas, livres ou adnatas na base, alvo-alaranjadas, estigma plumoso, decurrente ou reto. Drupas ovais. Sementes alvo-amareladas.

Material selecionado: MINAS GERAIS: Muriaé, Rio Muriaé, 17.XI.2001, L.S. Leoni 4786 (GFJP). Tombos, APA da Água Santa de Minas, 14.VI.2007, L.S. Leoni 6894 (SP). RIO DE JANEIRO: Itaperuna, lado direito da estrada sentido Natividade, 23.IX.2011, G. Pelissari et al. 205 (SP).

Ficus clusiifolia é posicionado por Berg \& Villavicencio (2004) no complexo americana. Este caracteriza-se por apresentar sicônios que nascem abaixo das folhas ou ramifloria. Para esses autores a espécie encontrada no sudeste brasileiro, incluindo 
a Mantiqueira, é F. clusiifolia, que se distingue das demais espécies do complexo pelos sicônios com até $5 \mathrm{~mm}$ diâm., pedúnculo curto (1-3 mm compr.), e epibrácteas relativamente grandes ( $2-3 \mathrm{~mm}$ compr.). Ficus clusiifolia é morfologicamente próxima à $F$. mathewsii (Miq.) Miq., outra entidade do complexo, encontrada na bacia amazônica. No entanto, as folhas, sicônios e epibrácteas são menores, se comparadas à F. clusiifolia (Berg \& Villavicencio 2004).

Seu nome popular é figueira.

Tem como habitat a floresta estacional semidecidual. A espécie pode ser encontrada próximo a estradas e cursos d'água, crescendo em pleno sol, em altitudes que variam de 110 a $580 \mathrm{~m}$. Possui dois registros em unidades de conservação, as demais coletas foram feitas em áreas de elevada ação antrópica. Espécie considerada "Próxima à Ameaçada", NT, devido à fragmentação e destruição de habitat.

5. Ficus eximia Schott in Spreng., Syst. Veg., ed. 16. 4 (2, App.): 409. 1827. Ficus glabra Vell., Fl. Flumin. Icon. 11. t. 50. (1827) 1831 . Fig. 3a-g

Árvores ou hemiepífitas 5-22 m alt.; látex branco, ralo; ramos 3-7 mm diâm., castanho claros, glabros. Estípulas 9-25 mm compr., caducas, esverdeadas, marrom quando secas, face dorsal glabra, face ventral glabra a pubérula, tricomas amarelos concentrados no ápice. Lâminas elípticas a oblongas, 8,5-27 × 3-15,5 cm, cartáceas a coriáceas, ápice acuminado a cuspidado, base cordada, subcordada a truncada, glabras em ambas as faces, macias; 7-15 pares de nervuras secundárias, proeminentes na face abaxial; pecíolos 5-12,5 cm compr., glabros, epiderme persistente, glândula acropeciolar. Sicônios aos pares, globosos, 5-10 mm diâm., lisos, pubérulos, tricomas alvo-esverdeados, macios, verdes, castanho quando secos, máculas creme; pedúnculos 1-4 mm compr., pubérulos, tricomas alvo-esverdeados; ostíolo proeminente, circular, 2-3 mm diâm.; 3 orobrácteas externas; 2 epibrácteas, face ventral serícea, tricomas alvo-amarelados, face dorsal pubérula, tricomas alvos. Flores estaminadas sésseis ou pediceladas: 2-3 tépalas, livres, alvo-amareladas, 1 estame; flores pistiladas: $2-3$ tépalas, livres, alvo-amareladas, estigma plumoso, decurrente ou reto. Drupas ovais. Sementes alvo-amareladas.

Material selecionado: MINAS GERAIS: Carangola, Serra da Caiana, 1.IV.2000, L.S. Leoni \& E. Dias 4405 (GFJP, RB). Ponte Nova, margem do rio Piranga, III.1997, L.V. Costa (SP 423589). Rio Preto, Sítio da figueira, 18.VIII.1997, F.R.S. Pires \& P.H. Nobre (CESJ 54833). RIO DE JANEIRO: Itatiaia, distrito de Penedo, margem direita do rio das Pedras, 23.III.2002, P.P. Souza 147 (RB). SÃO PAULO: Monte Alegre do Sul, E. E. Monte Alegre, 16.VI.1994, L.C. Bernacci et al. 407 (IAC, SP). Roseira, próximo ao Centro de Estudos Ambientais do Vale do Paraíba (CEAVAP), 15.II.2011, G. Pelissari et al. 195 (SP).

Ficus eximia é comumente identificada como F. glabra Vell. nos trabalhos sobre o gênero (Carauta 1989; Carauta \& Diaz 2002a; Machado \& Pederneiras 2007; Souza 2009; Pederneiras 2011). Carauta (1989) adota como nome válido para o táxon F. glabra, justificando sua decisão pelo fato de a descrição de Schott se apresentar insuficiente para caracterizar o táxon e o material tipo encontrar-se em estado vegetativo. No entanto, o binômio foi validamente publicado, não podendo ser substituído por um binômio de publicação efetiva com data posterior, de acordo com o Código Internacional de Nomenclatura Botânica (Mcneill et al. 2006).

Um caráter observado em $F$. eximia foi a coloração das folhas que se mantém verdes mesmo quando secas, sendo este um caráter único para essa espécie na Mantiqueira. Adota-se o proposto por Berg \& Villavicencio (2004) e Romaniuc Neto et al. (2009), considerando como binômio válido $F$. eximia e F. glabra como sinônimo.

Seus nomes populares são figueira, figueira brava, gameleira.

Tem como habitat a floresta ombrófila densa submontana e montana e floresta estacional semidecidual submontana e montana. Ficus eximia é encontrada crescendo geralmente em pleno sol, $\mathrm{em}$ altitudes que variam de $400 \mathrm{~m}$ a $780 \mathrm{~m}$. Possui registros em unidades de conservação, particulares e em áreas não protegidas, além de possuir ampla distribuição na Mantiqueira. Espécie considerada em "Menor Preocupaçao", LC.

6. Ficus gomelleira Kunth emend. Carauta \& Diaz, Index Seminum Hort. Bot. Berol. 1846: 18. 1847. Albertoa ser. Urticineae (Urticales) 10: 67-68. 2002.

Fig. 3h-1

Árvores ou hemiepífitas 11-20 m alt.; látex branco, espesso; ramos 0,5-1 cm diâm., castanhoclaros a castanho-avermelhados, tomentosos, tricomas ferrugíneos. Estípulas 1-2,5 cm compr., caducas, verdes, seríceas, tricomas tomentosos, ferrugíneos. Lâminas elípticas, ovadas a oblongas, 6-26 × 3-16 cm, coriáceas, ápice arredondado a acuminado, base cordada; face adaxial pubescente, tricomas ferrugíneos, macia, face abaxial tomentosa, tricomas ferrugíneos, macia; 9-13 pares de nervuras secundárias, proeminentes na face abaxial; pecíolos 2-4,5 cm compr., tomentosos, tricomas ferrugíneos, 


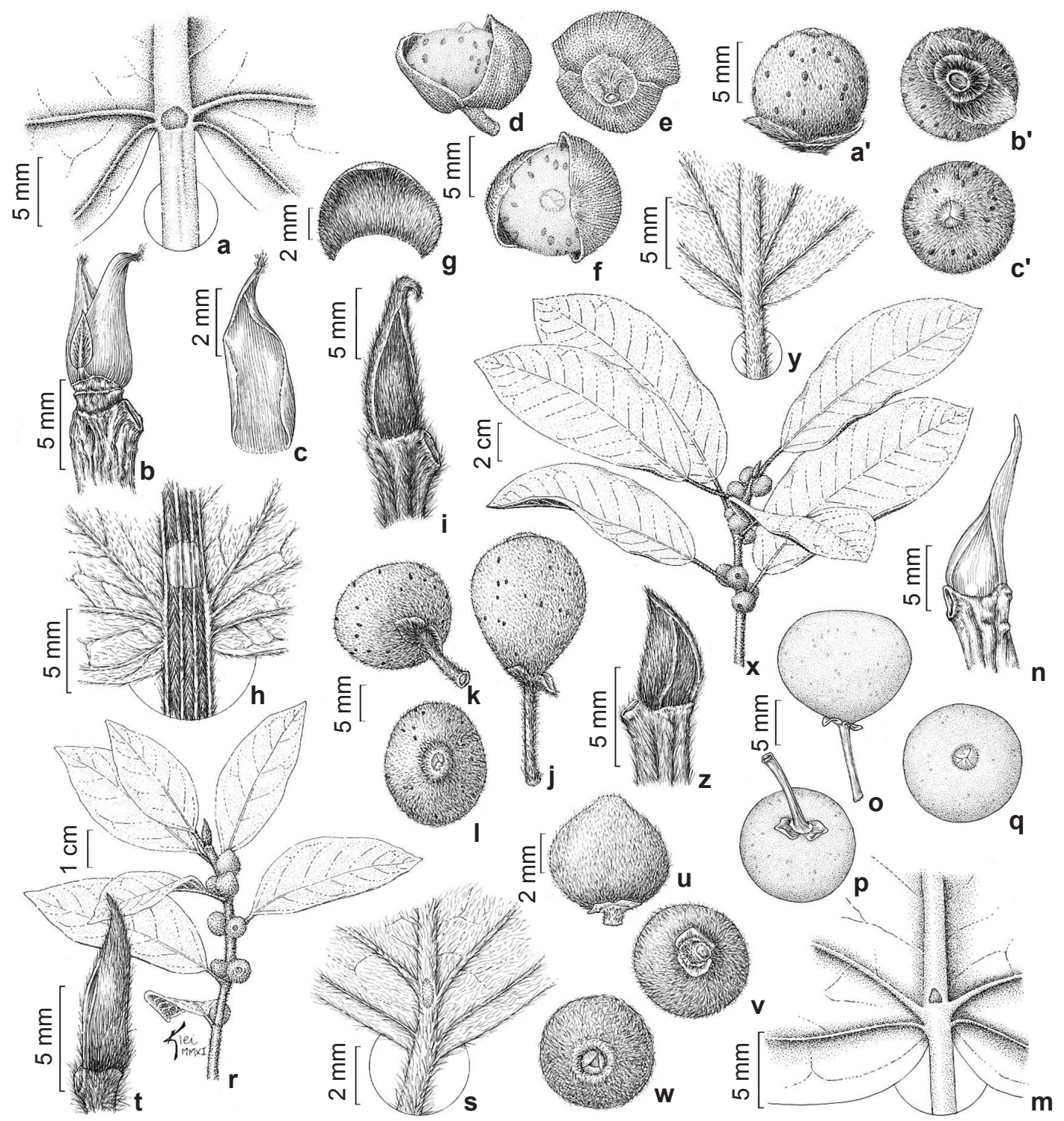

Figura 3 - a-g. F. eximia - a. base da lâmina foliar e glândula acropeciolar; b. estípula terminal no ramo; c. ápice da estípula com tricomas; d. sicônio; e. vista basal do sicônio e epibrácteas; f. vista apical do sicônio, ostíolo e orobrácteas; g. face ventral da epibráctea. h-1. F. gomelleira - h. base da lâmina foliar e glândula acropeciolar; i. estípula terminal no ramo; j. sicônio; k. vista basal do sicônio e epibrácteas; 1 . vista apical do sicônio, ostíolo e orobrácteas. m-q. F. guaranitica -m. base da lâmina foliar e glândula acropeciolar; n. estípula terminal no ramo; o. sicônio; p. vista basal do sicônio e epibrácteas; q. vista apical do sicônio, ostíolo e orobrácteas. r-w.F. hirsuta -r. ramo com folhas, estípula e sicônios; s. base da lâmina foliar e glândula acropeciolar; t. estípula terminal no ramo; u. sicônio; v. visão basal do sicônio e epibrácteas; w. visão apical do sicônio, ostíolo e orobrácteas. $\mathrm{x}-\mathrm{c}^{\prime} . F$. lagoensis - x. ramo com folhas, estípula e sicônios; y. base da lâmina foliar e glândula acropeciolar; z. estípula terminal no ramo; a'. sicônio; b'. visão basal do sicônio e epibrácteas; c'. visão apical do sicônio, ostíolo e orobrácteas (a-g Mendonça-Souza 44; h-1 Pelissari 193; m-q Vieira 2210; r-w Forzza 2224; x-c' Pelissari 211). Figure 3 - a-g. F. eximia - a. base of the leaf and acropetiolar gland; b. terminal stipule on the twig; c. stipule apex with trichomes; d. syconium; e. syconium basal view and epibracts; f. syconium apical view and orobracts; g. epibract ventral surface. h-1. F. gomelleira - h. base of the leaf and acropetiolar gland; i. terminal stipule on the twig; j. syconium; k. syconium basal view and epibracts; 1 . syconium apical view and orobracts. m-q. $F$. guaranitica $-\mathrm{m}$. base of the leaf and acropetiolar gland; $\mathrm{n}$. terminal stipule on the twig; o. syconium; p. syconium basal view and epibracts; $\mathrm{q}$. syconium apical view and orobracts. r-w. F. hirsuta -r. twig with leaves, stipule and syconiums; s. base of the leafand acropetiolar gland; t. terminal stipule on the twig; u. syconium; v. syconium basal view and epibracts; w. syconium apical view and orobracts. x-c'. F. lagoensis - x. twig with leaves, stipule and syconiums; $y$. base of the leaf and acropetiolar gland; $z$. terminal stipule on the twig; a'. syconium; b'. syconium basal view and epibracts; c'. syconium apical view and orobracts (a-g Mendonça-Souza 44; h-1 Pelissari 193; m-q Vieira 2210; r-w Forzza 2224; x-c' Pelissari 211). 
epiderme persistente, glândula acropeciolar. Sicônios aos pares, globosos, 1,3-2 cm diâm., lisos, pilosos a tomentosos, tricomas alvos a ferrugíneos, verdes, castanhos quando secos, máculas creme a castanhoescuro; pedúnculos 6-13 $\mathrm{mm}$ compr., tomentosos, tricomas ferrugíneos; ostíolo 1-2 mm diâm., plano, circular, anel circular; 3 orobrácteas externas; 2 epibrácteas, face ventral glabra, face dorsal pilosa, tricomas ferrugíneos. Flores estaminadas pediceladas: 3 tépalas, livres ou adnatas na base, alvo-rosadas, 1 estame; flores pistiladas: 3 tépalas, livres ou adnatas na base, alvo-rosadas, estigma plumoso, decurrente ou reto. Drupas globosas a ovais. Sementes amareladas.

Material selecionado: ESPÍRITO SANTO: Dores do Rio Preto, Três Estados, 12.X.2000, E.A. Costa 82 (RB). MINAS GERAIS: Carangola, Fazenda Santa Rita, 24.IX.2011, G. Pelissari et al. 207 (SP). Caratinga, APA Lagoa Silvana, 5.X.2002, M.O.D. Pivari \& L.G.S. Soares 159 (CESJ). Descoberto, Reserva Biológica da Represa do Grama, 10.XI.2001, R.M. Castro et al. 659 (BHCB, HUFU, RB). Lima Duarte, 28.VII.1979, L. Krieger \& M. Sabino 16299 (CESJ, GUA, HUFU, MBM, SP). Ponte Nova, III.1997, L.V. Costa (BHCB 37493, RB). São João Nepomuceno, Serra do Núcleos, 11.II.2003, R.M. Castro et al. 782 (CESJ). RIO DE JANEIRO: Itatiaia, Distrito de Penedo, 23.III.2002, P.P. Souza 144 (R, RB). Natividade, Fazenda de Edésio Barbosa da Silva, XI.1979, R. Ribeiro 38 (GUA). SÃO PAULO: Pindamonhangaba, bairro de Taipas, 15.II.2011, G. Pelissari et al. 194 (SP).

Ficus gomelleira foi publicada, junto com outras 67 espécies do gênero em um artigo organizado e publicado por Kunth (1847). No mesmo ano Miquel (1847) publicou uma nova combinação para a espécie, Urostigma gomelleira, atribuindo a autoria da espécie a Kunth \& Bouché. A partir dessa publicação vários autores (Berg et al. 1984; Carauta 1989; Berg \& Simonis 2000; Berg \& Villavicencio 2004) atribuíram a autoria de F. gomelleira a Kunth \& Bouché. No entanto, o capítulo onde estão descritas as espécies de Ficus foi publicada por Kunth, cabendo unicamente a ele a autoria da espécie, como apontado por Carauta $\& \operatorname{Diaz}(2002 b)$.

Seus nomes populares são figueira, gameleira, gameleira branca.

Tem como habitat a floresta estacional semidecidual submontana e montana. Ficus gomelleira pode ser encontrada em pastagens e também próximo a cursos d'água, crescendo em pleno sol, em altitudes que variam de 210 a $730 \mathrm{~m}$. Espécie considerada em "Menor Preocupação", LC, por apresentar registros em unidades de conservação e particulares, além de possuir ampla distribuição na Mantiqueira.
7. Ficus guaranitica Chodat in Chodat \& Vischer, Bull. Soc. Bot. Genève, ser. 2. v. 11: 254. 1920.

Fig. $3 \mathrm{~m}-\mathrm{q}$

Árvores ou hemiepífitas 5-7 m alt; látex branco a creme, ralo; ramos 3-5 mm diâm., castanho-acinzentados, glabros. Estípulas 6-15 $\mathrm{mm}$ compr., caducas, verdes a avermelhadas, vináceas quando secas, glabras. Lâminas oblongas, 8,5-15,5 × 5,5-8,5 cm compr., cartáceas, ápice acuminado, base cordada; glabra em ambas as faces, macia; (10-)11-13 pares de nervuras secundárias, planas na face abaxial; pecíolos $(2,5-) 5,5-7 \mathrm{~cm}$ compr., glabros, epiderme persistente, glândula acropeciolar. Sicônios aos pares, piriformes, 7-12 mm diâm., lisos, glabros a pubérulos, tricomas alvos; esverdeados, macios, castanhos quando secos, máculas alvo-esverdeadas, pedúnculos 4-12 mm compr., glabros a pubérulos, tricomas inconspícuos; ostíolo plano, circular, 2-3 mm diâm.; 3 orobrácteas externas; 2 epibrácteas, glabras em ambas as faces. Flores estaminadas pediceladas: 2-3 tépalas, livres ou adnatas na base, alvas, 1 estame ; flores pistiladas: $2-3$ tépalas, livres ou adnatas na base, alvas, estigma plumoso, decurrente ou reto. Drupas globosas. Sementes alvo-amareladas.

Material selecionado: MINAS GERAIS: Alfenas, Fazenda do Porto, 1991, M.C.W. Vieira 1807 (RB); RPPN Jequitibá, 30.IV.2007, M.C.W. Vieira 2203 (RB); 18.V.2007, M.C.W. Vieira 2210 (RB). SÃO PAULO: Pinhal, bairro das três fazendas, 15.XI.1947, M. Kuhlmann 1558 (SP).

Ficus guaranitica é tratada por Berg \& Villavicencio (2004) como sinônimo de $F$. citrifolia, que o descreve com folhas de base cordada, sicônios globosos a obovóides e ostíolo plano a levemente proeminente. Carauta (1989) as diferencia pelas características do formato do sicônio, ostíolo e tamanho do pedúnculo. Ficus guaranitica é a única espécie da área estudada a apresentar sicônio piriforme.

Seu nomes popular é figueira.

Tem como habitat a floresta estacional semidecidual. Espécie encontrada em borda de mata, em altitudes que variam de 800 a $1100 \mathrm{~m}$. Espécie considerada "Próxima à Ameaçada", NT, por possuir apenas quatro registros na região, sendo apenas dois deles em unidades de conservação.

8. Ficus hirsuta Schott in Spreng., Syst. Veg. 4 (2, App.): 410. 1827. Ficus hirsuta Vell., Fl. Flumin. Icon. 11. t. 49. (1829) $1831 . \quad$ Fig. 3r-w

Árvores 5-7 m alt; látex branco, ralo. Ramos 3-4 mm diâm., castanhos, hirsutos, tricomas alvos. Estípulas 5-9 mm compr., caducas, castanhas quando 
secas, hirsutas, tricomas alvos. Lâminas elípticas, 2,5-5 × 1,5-2,5(-3) cm, cartáceas, ápice agudo a acuminado, base aguda a arredondada; hirsuta em ambas as faces; 5-7 pares de nervuras secundárias, planas na face abaxial; pecíolos 4-8 $\mathrm{mm}$ compr., hirsutos, tricomas alvos, epiderme persistente, glândula acropeciolar. Sicônios aos pares, globosos, 5-6 mm diâm., lisos, verdes a roxos, castanhos quando secos, macios, hirsutos, tricomas alvos, máculas vináceas; pedúnculos 1-2 mm compr., hirsutos, tricomas alvos; ostíolo ca. $1 \mathrm{~mm}$ diâm., plano a proeminente, circular, 3 orobrácteas externas; 2 epibrácteas, face ventral glabra, face dorsal hirsuta, tricomas alvos. Flores estaminadas pediceladas: 2 tépalas, livres ou adnatas na base, alvas, 1 estame; flores pistiladas: 2 tépalas, livres ou adnatas na base, alvas, estigma plumoso, reto. Drupas globosas. Sementes amareladas.

Material selecionado: MINAS GERAIS: Descoberto, Reserva Biológica da Represa do Grama, 22.IX.2002, R.C.Forzza et al. 2224 (CESJ, MBM, SPF).

Ficus hirsuta foi descrita tanto por Schott (1827) quanto por Vellozo (1831). Carauta (1989) ressalta que os 11 volumes da obra de Vellozo foram consultados por botânicos estrangeiros que visitaram o Rio de Janeiro, antes da publicação da obra em Paris. Pode ter havido coincidência na escolha do nome ou Schott pode ter optado por manter o binômio dado por Vellozo. De acordo com o Código Internacional de Nomenclatura Botânica (Mcneill et al. 2006) tem prioridade o nome mais antigo publicado, sendo, portanto considerado como nome válido para o táxon F. hirsuta Schott. A espécie é considerada por Carauta (1989) e Carauta \& Diaz (2002a) morfologicamente similar à $F$. organensis, pois ambas apresentam folhas e sicônios reduzidos. Na Mantiqueira podem ser diferenciadas pelas características do indumento foliar, sendo hirsuto em $F$. hirsuta e glabro em $F$. organensis.

Tem como habitat a floresta estacional semidecidual. Ficus hirsuta pode ser encontrada em borda de mata, em altitude de $340 \mathrm{~m}$. Apesar de ser encontrada em unidade de conservação, a espécie possui apenas um registro na região, podendo indicar uma escassez de fontes de imigração de propágulos. Espécie considerada "Criticamente em perigo", CR devido a baixa extensão de ocorrência da espécie, B1.

\section{Ficus lagoensis C.C. Berg \& Carauta, Brittonia} 54(4): 243. 2003.

Fig. 3x-c'

Árvores ou hemiepífitas 15-20 m alt.; látex branco, ralo; ramos 3-5 $\mathrm{mm}$ diâm., castanho acinzentados a castanho escuros, pubescentes a hirtelos, tricomas alvos. Estípulas 4-10 mm compr., caducas, verdes, castanhas quando secas, seríceas, tricomas alvos. Lâminas elípticas a ovais, 6-13,5 $\times 3-6,5 \mathrm{~cm}$, cartáceas a coriáceas, ápice agudo a arredondado, base truncada; face adaxial pubérula, hirsuta na região das nervuras, tricomas alvos, macia, face abaxial hirsuta, tricomas alvos, macia; 6-10 pares de nervuras secundárias, planas na face abaxial; pecíolos 1,3-3 cm compr., hirtelos, tricomas alvos epiderme persistente, glândula acropeciolar. Sicônios aos pares, globosos, 4-8 mm diâm., lisos, seríceos, tricomas alvos, macios, verdes, castanhoavermelhados quando secos, máculas avermelhadas quando secas; sésseis; ostíolo plano a proeminente, circular, ca. 1 mm diâm., 3 orobrácteas externas; 2 epibrácteas, face ventral glabra, face dorsal serícea, tricomas alvos. Flores estaminadas não observadas; flores pistiladas: 3 tépalas, livres ou adnatas na base, alvas, estigma plumoso, reto. Drupas ovais. Sementes amareladas.

Material selecionado: MINAS GERAIS: Alfenas, Fazenda da Ilha, 18.V.1987, M.C.W. Vieira 1165 (RB, SP). Barroso, Mata do Baú, 13.IV.2001, L.C.S. Assis \& M.K. Ladeira 80 (CESJ, ESA, GUA). Caldas, Propriedade do Prof. Roberto Noritaka, 24.X.2011, G. Pelissari et al. 211 (SP). Camanducaia, mata ciliar degradada do rio Jaguari, 24.XI.1999, R.B. Torre et al. 963 (IAC). Entre Rios de Minas, I.1970, L. Krieger 8329 (CESJ, SP). SÃO PAULO: Amparo, Cachoeira do Rio Camanducaia, 22.XII.1942, M. Kuhlmann 286(SP). Queluz, 23.VI.1999, Sem coletor 64 (SP 23850).

Ficus lagoensis é considerada, por Berg \& Villavicencio (2004) morfologicamente similar à $F$. hirsuta devido ao indumento hirsuto das folhas de ambas. Mendonça-Souza (2006), ao estudar Ficus do estado de São Paulo, considera F. lagoensis como sinônimo de F. hirsuta. Entretanto, é possível notar uma sobreposição dos caracteres apontados por Berg \& Villavicencio (2004) nos materiais analisados pelos autores. Para a Mantiqueira $F$. lagoensis e $F$. hirsuta são tratadas como táxons distintos, aceitando como caracteres distintivos os apontados por Berg \& Carauta (2002).

Seu nome popular é figueira.

Tem como habitat o cerrado e floresta estacional semidecidual. Ficus lagoensis pode ser encontrada em pastagens e próxima a cursos d'água, em mata ciliar, em altitudes que variam de 490 a 1100 m. Há apenas um registro em unidade de conservação. As demais coletas localizamse em áreas de acelerada destruição de habitat. Espécie tratada como Vulnerável, VU devido a fragmentação e qualidade do habitat de ocupação da espécie, B2b(iii). 
10. Ficus luschnathiana (Miq.) Miq., Ann. Mus. Lugduno.-Batavi 3: 298. 1867. Urostigma luschnathianum Miq. in Martius, Fl. Bras. 4(1): 101. 1853. Ficus monckii Hassl., Ann. Conserv. Jard. Bot. Genève 21: 127. $1919 . \quad$ Fig. 4a-e

Árvores ou hemiepífitas 2-25 m alt.; látex branco, espesso; ramos 4-7 mm diâm., castanhoclaros a castanho-escuros, glabros. Estípulas 1-2 $\mathrm{cm}$ compr., caducas, esverdeadas a alaranjadas, avermelhadas quando secas, glabra em ambas as faces. Lâminas elípticas a oblongas, 6-20 × 3-7,5 $\mathrm{cm}$, cartáceas a coriáceas, ápice agudo a acuminado, base aguda a obtusa, glabra em ambas as faces, macia; 7-11 pares de nervuras secundárias, proeminentes na face abaxial; pecíolos 1,5-7 cm compr., glabros, epiderme persistente, glândula acropeciolar. Sicônios aos pares, globosos, 8-10 mm diâm., lisos, glabros, verdes, vináceos na maturação, verdes a castanhos quando secos, máculas brancas; sésseis; ostíolo plano, circular, anel circular ausente, $2-4 \mathrm{~mm}$ diâm.; 2 orobrácteas externas, raro 3; 2 epibrácteas, glabra em ambas as faces. Flores estaminadas pediceladas: $2-3$ tépalas, livres ou adnatas na base, alvo-amareladas, 1 estame; flores pistiladas: $2-3$ tépalas, livres ou adnatas na base, alvo-amareladas, estigma plumoso, decurrente ou reto. Drupas globosas. Sementes alvo-amareladas.

Material selecionado: MINAS GERAIS: Caldas, Propriedade do Zé Painha, 24.X.2011, G. Pelissari et al. 208 (SP). Camanducaia, Mata do Ferreirinha, 28.VIII.1999, J.R. Stehmann 2575 (BHCB, CESJ, SPF). Caxambu, Fazenda Juca Leite, 26.II.1987, P.L. Senna 2 (RB). Rio Preto, Funil, 20.II.2004, L.C.S. Assis et al. 1008 (CESJ). RIO DE JANEIRO: Itatiaia, distrito de Maringá, margem direita do rio das Cruzes, 16.II.2011, G. Pelissari et al. 200 (SP). SÃO PAULO: Amparo, margem do rio Camanducaia, 18.XII.1942, M. Kuhlmann 174 (SP). Atibaia, 18.XI.1987, J.A.A. Meira Neto et al. 335 (GUA, UEC). Campos do Jordão, Parque Estadual de Campos do Jordão, 14.VI.1984, J.P.M. Carvalho \& M.J. Robim 100 (GUA, SPSF). Jundiaí, Reserva Biológica Municipal da Serra do Japi, 22.IX.1983, S.C. Chiea 342 (SP). Monteiro Lobato, Serra da Mantiqueira, 8.XI.1953, M. Kuhlmann 2913 (SP). São Paulo, Parque Estadual do Jaraguá, 26.VII.2007, F.M. Souza et al. 861 (SPSF).

Ficus luschnathiana é geralmente determinada, principalmente nos estados de São Paulo, Paraná e Santa Catarina, como F. enormis (Miq.) Miq. Carauta (1989) as difere principalmente pela inserção dos sicônios nos ramos, sendo que a primeira apresenta sicônios distribuídos ao longo dos ramos e a segunda sicônios aglomerados no ápice dos ramos. Este caráter não pode ser adotado para a separação dos táxons, pois ambos foram observados em um mesmo indivíduo. Foi possível notar, que há diferenças entre ramos jovens e ramos mais velhos. Os ramos mais jovens apresentam folhas maiores, entrenós mais espaçados e sicônios distribuídos nos ramos, enquanto os ramos mais velhos apresentam folhas menores, entrenós curtos e sicônios aglomerados no ápice dos ramos. A partir da análise dos exemplares coletados com o isótipo de $F$. luschnathiana e de material coletados pelos autores em Cabo Frio, localidade típica da espécie, foi possível concluir que o táxon ocorrente na Mantiqueira, principalmente em São Paulo e Rio de Janeiro, é $F$. luschnathiana. O material tipo de $F$. enormis encontra-se em estado vegetativo e as folhas mostram-se obovadas, característica não encontrada nos espécimes examinados da Mantiqueira. Apesar de Carauta \& Diaz (2002a) salientarem que o tipo de $F$. enormis possui exemplares procedentes de São Paulo e Minas Gerais, nenhum indivíduo coletado pelos autores na Mantiqueira, nos estados de São Paulo e Rio de Janeiro apresenta folhas obovadas, de base arredondada a subcordada, o mesmo ocorrendo com alguns indivíduos coletados em Minas Gerais. Pelo exposto acima, adotamos o posicionamento de Berg \& Villavicencio (2004) e Romaniuc Neto et al. (2009), considerando os materiais examinados da Mantiqueira, que apresentam folhas elípticas, como pertencentes a $F$. luschnathiana. Assim como Mendonça-Souza (2006), não trataremos $F$. enormis como sinônimo, uma vez que se assemelha mais a F. mexiae Standl.

Seus nomes populares são figueira, figueira da pedra, mata-pau, gameleira-vermelha.

Tem como habitat a floresta ombrófila densa montana, floresta estacional semidecidual montana, floresta ombrófila mista e cerrado. Espécie frequentemente encontrada desenvolvendo-se sobre afloramento rochoso, em interior ou borda de mata e também em mata ciliar, em altitudes que variam de 400 a $1300 \mathrm{~m}$. Possui de ampla distribuição na Mantiqueira, principalmente nas porções paulista e fluminense, com registros em unidades de conservação. Espécie apresenta "Menor Preocupação", LC.

11. Ficus mariae C.C. Berg, Emygdio \& Carauta, Bradea 8(20): 112. 1999.

Fig. $4 \mathrm{f}-\mathrm{k}$

Árvores 8-32 m alt.; látex branco, espesso; ramos 2-7 mm diâm., castanhos a avermelhados, pubescentes, tricomas alvos a castanhos. Estípulas 


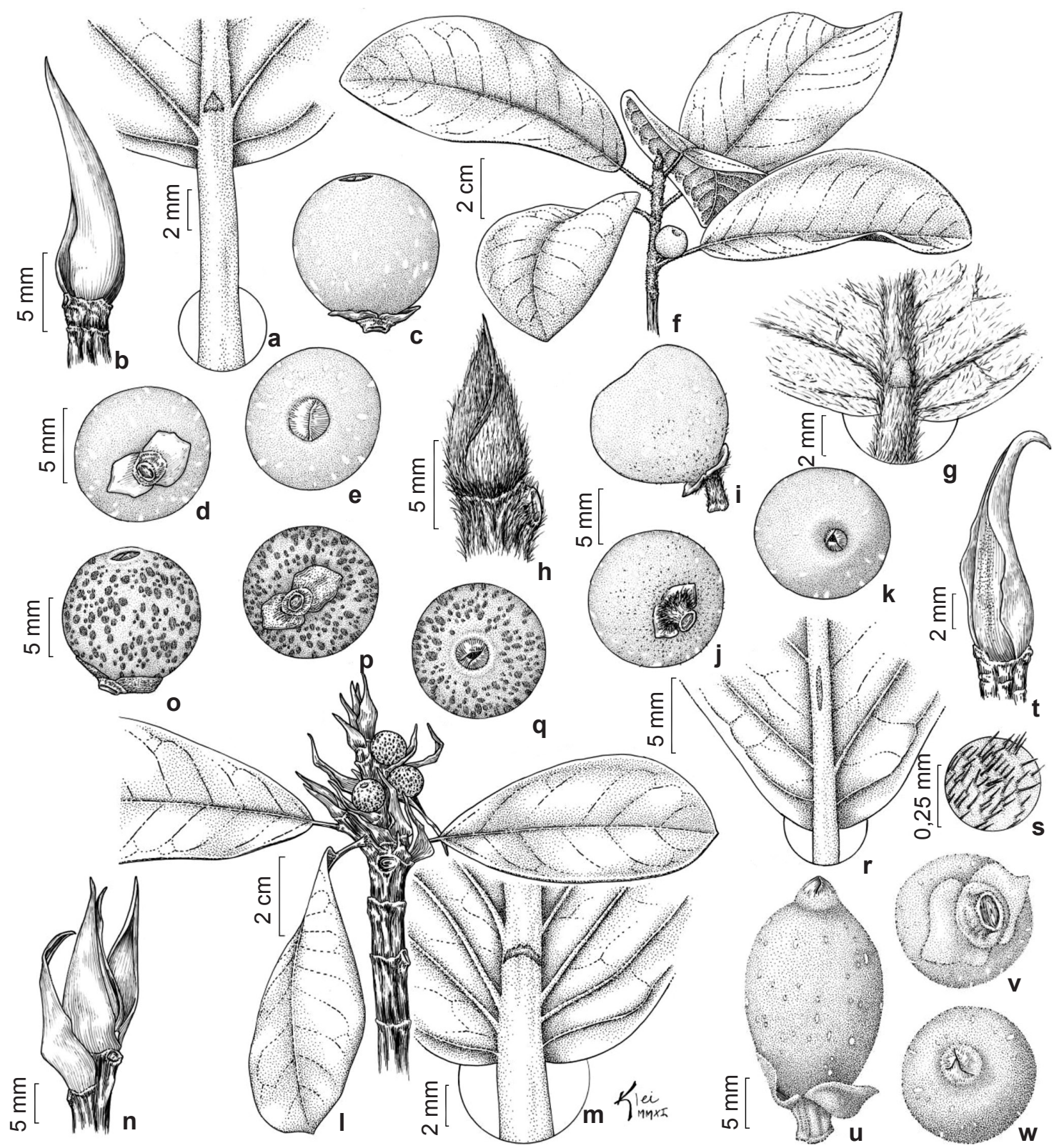

Figura 4 - a-e. F. luschnathiana - a. base da lâmina foliar e glândula acropeciolar; b. estípula terminal no ramo; c. sicônio; d. vista basal do sicônio e epibrácteas; e. vista apical do sicônio, ostíolo e orobrácteas. f-k. F. mariae - f. ramo com folhas, estípula e sicônios; g. base da lâmina foliar e glândula acropeciolar; h. estípula terminal no ramo; i. sicônio; j. visão basal do sicônio e epibrácteas; k. visão apical do sicônio, ostíolo e orobrácteas. 1-q. F. mexiae - 1. ramo com folhas, estípula e sicônios; m. base da lâmina foliar e glândula acropeciolar; n. estípula terminal no ramo; o. sicônio; p. visão basal do sicônio e epibrácteas; q. visão apical do sicônio, ostíolo e orobrácteas. r-w. F. obtusifolia - r. base da lâmina foliar e glândula acropeciolar; s. indumento dos sicônios; t. estípula terminal no ramo; u. sicônio; v. visão basal do sicônio e epibrácteas; w. visão apical do sicônio, ostíolo e orobrácteas (a-e Pelissari 200; f-k Nishimura 28; 1-q Souza 251; r-w Romaniuc Neto 1365). Figure 4 - a-e. F. luschnathiana - a. base of the leaf and acropetiolar gland; b. terminal stipule on the twig; c. syconium; d. syconium basal view and epibracts; e. syconium apical view and orobracts. f-k. F. mariae - f. twig with leaves, stipule and syconiums; g. base of the leaf and acropetiolar gland; h. terminal stipule on the twig; i. syconium; j. syconium basal view and epibracts; k. syconium apical view and orobracts. l-q. F. mexiae - 1. twig with leaves, stipule and syconiums; m. base of the leaf and acropetiolar gland; n. terminal stipule on the twig; o. syconium; p. syconium basal view and epibracts; q. syconium apical view and orobracts. r-w. F. obtusifolia - r. base of the leaf and acropetiolar gland; s. syconiums indument; t. terminal stipule on the twig; u. syconium; v. syconium basal view and epibracts; w. syconium apical view and orobracts (a-e Pelissari 200; f-k Nishimura 28; 1-q Souza 251; r-w Romaniuc Neto 1365). 
ca. $1 \mathrm{~cm}$ compr., caducas, vináceas, hirsutas, alvos a castanhos. Lâminas elípticas a oblongas, 6-13 × 4,5-7 cm, subcoriácea, ápice agudo a levemente cuspidado, base arredondada, glabras em ambas as faces, com pilosidade restrita às nervuras principal e secundárias, tricomas alvos a castanhos; 11-14 pares de nervuras secundárias, proeminentes na face abaxial; pecíolos 1-2 cm compr., hirsutos, alvos a castanhos, epiderme persistente, glândula acropeciolar. Sicônio aos pares, globosos, 8-10 mm diâm., lisos, glabros a pubérulos, tricomas alvos a castanhos quando secos, macios, máculas creme; pedúnculos 2-4 mm compr., glabros a pubérulos, tricomas alvos a castanhos; ostíolo crateriforme, circular, 2-3 mm diâm.; 3 orobrácteas externas; 2 epibrácteas, face ventral glabra, face dorsal hirsuta, tricomas alvos a castanhos. Flores estaminadas sésseis a pediceladas: 3 tépalas, livres, alvoamareladas, 1 estame; flores pistiladas: 3 tépalas, livres, alvo-amareladas, estigma bífido, liso, reto. Drupas ovais. Sementes alvo-amareladas.

Material selecionado: MINAS GERAIS: Carangola, Rio Carangola, 20.VIII.1989, L.S. Leoni 834 (GFJP). Caratinga, Estação Biológica de Caratinga, 1.X.1984, K.B. Strier 662 (RB); Fazenda Montes Claros, 9.I.1980, A. Nishimura 28 (RB). Viçosa, estrada para Airões, 9.XI.2007, P.P. Souza 210 (GFJP, VIC).

Ficus mariae foi identificada em alguns exemplares de herbário consultados como $F$. matiziana Dugand, devido à semelhança na pilosidade das lâminas e formato do ostíolo. No entanto, as lâminas de F. matiziana apresentam nervura principal avermelhada, não observado em $F$. mariae. Além disso, em $F$. matiziana o ostíolo, apesar de ser crateriforme, apresenta um anel elevado, tri-bracteado (Carauta 1989), essa característica não ocorrendo em F. mariae. Também diferem quanto à distribuição geográfica sendo, $F$. matiziana, encontrada na região amazônica, Colômbia, Venezuela e Guianas, enquanto $F$. mariae, apesar de ser encontrada na Bolívia e Peru, possui distribuição extra-amazônica (Berg \& Villavicencio 2004). Pode ser confundida com $F$. trigona, quando em estado vegetativo, mas se diferencia desta por apresentar sicônios sésseis e ostíolo crateriforme, circular, enquanto $F$. trigona apresenta sicônios pedunculados com ostíolo crateriforme, triangular.

Seu nome popular é figueira de Maria.

Tem como habitat a floresta estacional semidecidual submontana. Ficus mariae pode ser encontrada em solo brejoso ou próximo a cursos d'água, crescendo em pleno sol, em altitudes que variam de 400 a $770 \mathrm{~m}$. Além de possuir poucas coletas na Mantiqueira possui apenas uma referência em unidade de conservação. A espécie ocorre nas vizinhanças da Mantiqueira, sendo uma fonte de imigração de propágulos, no entanto sofre pressão antrópica na área de estudo, devendo ser tratada como "Em Perigo", EN devido a qualidade e fragmentação da área de ocorrência da espécie, Bla,b(iii).

12. Ficus mexiae Standl., Publ. Field Mus. Nat. Hist., Bot. Ser. 17(2): 173. $1937 . \quad$ Fig. 41-q Árvores ou hemiepífitas 6-15 m alt.; látex branco, espesso; ramos 3-8 mm diâm., castanho escuros, glabros. Estípulas 1,2-2,5 cm compr., persistentes, esverdeadas, castanhas quando secas, glabra em ambas as faces. Lâminas obovadas a oblanceoladas, 6-18,5 × 2-8 cm, coriáceas, ápice arredondado, acuminado a obtuso, base arredondada a hastado-cordada, glabras em ambas as faces, macias; 8-12 pares de nervuras secundárias, proeminentes na face abaxial; pecíolos 0,7-3,5 cm compr., glabros, epiderme persistente, glândula acropeciolar. Sicônios aos pares, globosos, 0,5-1,5 cm diâm., lisos, glabros; verdes, castanhos quando secos, macios, máculas brancas a esverdeadas, castanho escuro quando secas; sésseis; ostíolo plano, circular, anel circular presente, 1-4 mm diâm; 2 orobrácteas externas; 2 epibrácteas, glabras em ambas as faces. Flores estaminadas pediceladas: 2 tépalas, adnatas na base, castanhas, 1 estame; flores pistiladas: 3 tépalas, adnatas na base, castanhas, estigma bífido, plumoso ou reto. Drupas globosas. Sementes amareladas.

Material selecionado: ESPÍRITO SANTO: Dores do Rio Preto, Mundo Novo, 15.III.2001, E.A. Costa 87 (RB). MINAS GERAIS: Alto Caparaó, Parque Nacional do Caparaó, 27.IX.2007, T.T. Carrijo et al. 1058 (R, RB). Araponga, Serra do Brigadeiro, Fazenda Brigadeiro, VI.1996, L.S. Leoni 3392 (GFJP, GUA). Barroso, Mata do Baú, 25.XI.2001, L.C.S. Assis \& M.S. Magalhães 391 (CESJ, GUA). Descoberto, Reserva Biológica da Represa do Grama, 18.V.2002, A.V. Lopes et al. 47 (CESJ, RB). Itamarati de Minas, Mineração de Alumínio - CBA, I.1998, L.V. Costa (BHCB 14428). Juiz de Fora, Morro do Imperador, 7.XI.2001, D.S. Pifano \& M.O.D. Pivari 110 (CESJ, GUA). Olaria, São Domingos da Bocaina, 10.X.1989, L. Krieger et al. (SP 304101). Poços de Caldas, 1.IX.1980, J.Y. Tamashiro et al. 181 (UEC). Rio Preto, estrada do Funil, 21.III.2004, K. Antunes et al. 1 (CESJ). São João Nepomuceno, Serra dos Núcleos, 14.II.2003, R.M. Castro et al. 813 (CESJ). Viçosa, estrada para Canaã, Sítio sem peixe, 15.XII.2010, G. Pelissari et al. 192 (SP).

Ficus mexiae, assim como F. luschnathiana, geralmente são identificadas como $F$. enormis. Carauta (1989) reconhece as três espécies como 
binômios válidos, entretanto, Vazquez Avila (1985) já tinha proposto a sinonímia de $F$. mexiae sob $F$. enormis, o que também foi aceito por Berg $\&$ Villavicencio (2004). Estes últimos justificam sua decisão pelo fato de $F$. enormis apresentar variações quanto ao tamanho e formato das lâminas, comprimento do pedúnculo, presença de indumento, assim como o número de orobrácteas, tratando as características morfológicas de $F$. mexiae como variações de $F$. enormis. Carauta \& $\operatorname{Diaz}(2002 \mathrm{a})$ reafirmam a distinção entre $F$. enormis, $F$. luschnathiana e F. mexiae, considerando que o tipo de F. enormis, coletado por Martius apresenta, provavelmente, materiais de duas procedências, Minas Gerais e São Paulo.

Todos os materiais observados e coletados pelos autores, tanto em Viçosa como em outras localidades da Mantiqueira, apresentaram folhas obovadas de base arredondada a subcordada, características presentes no material tipo de $F$. mexiae, e as variações apontadas por Berg \& Villavicencio (2004) não foram encontradas. Tanto $F$. mexiae quanto $F$. enormis necessitam de estudos mais aprofundados, tanto moleculares quanto anatômicos, atualmente em desenvolvimento por Pedro Paulo de Souza (comunicação pessoal), para elucidar esse problema taxonômico. Diante do exposto, consideramos no presente trabalho apenas a ocorrência de $F$. mexiae para a Mantiqueira.

Seus nomes populares são figueira de mexia, gameleira, mata pau, figueira brava.

Tem como habitat a floresta ombrófila densa, floresta estacional semidecidual submontana e montana e cerrado. A espécie desenvolve-se tanto em solos brejosos como arenosos, em áreas sombreadas ou com luminosidade intensa, em altitudes que variam de 500 a 1400 m. Facilmente encontrada em áreas não preservadas, no entanto, há vários registros da espécie em unidades de conservação, além de ser amplamente distribuída na Mantiqueira, principalmente na região mineira. Espécie apresenta "Menor Preocupaçao", LC.

13. Ficus obtusifolia Kunth in Humb. \& Bonpl., Nov. Gen. Sp. 2: 49. 1817.

Fig. 4r-w

Árvores ou hemiepífitas 12-18 m alt.; látex branco, espesso; ramos ca. $5 \mathrm{~mm}$ diâm., castanhoclaros a marrom-escuros, glabros. Estípulas 1-1,7 cm compr., caducas, verdes, castanhoavermelhadas quando secas, glabras a pubescentes, tricomas alvos. Lâminas obovadas, 6-21 × 3-8 $\mathrm{cm}$, coriáceas, ápice arredondado, base aguda a cuneada, glabras em ambas as faces, macias;
7-10 pares de nervuras secundárias, planas na face abaxial; pecíolos 1-5 cm compr., glabros, epiderme persistente, glândula acropeciolar. Sicônios aos pares, oblongos, 1,5-2 cm diâm., lisos ou verrucosos, pubescentes, tricomas alvos, macios, verdes, castanho-claros a castanho-escuros quando secos, máculas creme, castanhas quando secas; pedúnculos 2-4 mm compr., pubérulos, tricomas alvos; ostíolo proeminente, circular, 3-4 mm diâm.; 3 orobrácteas externas; 2 epibrácteas, face ventral pubescente na base, tricomas alvos, face dorsal pubescente, tricomas alvos. Flores estaminadas pediceladas: 3 tépalas, livres, alvo-amareladas, 1 estame; flores pistiladas: 3-4 tépalas, livres, alvoamareladas, estigma plumoso, decurrente ou reto. Drupas subglobosas a ovais. Sementes amareladas. Material selecionado: MINAS GERAIS: Ewbank da Câmara, Fazenda Cascatinha, 13.IX.1994, H.G.P. Santos et al. 323 (CENARGEN, SP). SÃO PAULO: Águas de Lindóia, estrada de terra para Barão de Ataliba, 9.V.1995, J.Y. Tamashiro et al. 1037 (ESA, HRCB, SP, SPF). Aparecida, Fazenda Motuca, 4.XII.1999, E.A. Rodrigues (SP 397013).

Ficus obtusifolia foi circunscrita por Carauta (1989) de forma ampla, adotando F. gardneriana (Miq.) Miq. e F. mattogrossensis Standl. como sinônimos. Berg \& Villavicencio (2004) propõem a sinonímia desses três táxons, esclarecendo que os espécimes brasileiros são morfologicamente variáveis. Ainda afirmam que $F$. obtusifolia é espécie morfologicamente próxima a $F$. catappifolia Kunth \& Bouché, diferenciando-os de acordo com a base da lâmina foliar, número de nervuras secundárias, formato do sicônio e distribuição geográfica, sendo $F$. cattapifolia presente na região das Guianas. No entanto, Santos (2010) propõe a sinonímia de $F$. catappifolia em $F$. obtusifolia, uma vez que os indivíduos estudados apresentaram variações em todos os caracteres. Por apresentar lâminas de base aguda a cuneada e glabras, optouse por adotar a proposta de Berg \& Villavicencio (2004) e considerar, como táxon ocorrente na Mantiqueira, apenas F. obtusifolia.

Tem como habitat a floresta estacional semidecidual submontana. Espécie encontrada em altitudes que variam de $540 \mathrm{~m}$ a $1100 \mathrm{~m}$. Possui poucas coletas na área e nenhuma referência em unidade de conservação. Possui poucos registros nas vizinhanças da Mantiqueira, indicando uma escassez de fontes de imigração de propágulos. Espécie considerada "Vulnerável", VU devido a qualidade e fragmentação da área de ocorrência da espécie, B1a,b(i,iii). 
14. Ficus obtusiuscula (Miq.) Miq., Ann. Mus. Lugduno-Batavi 3: 300. 1867. Pharmacosycea obtusiuscula Miq., London J. Bot. 7: 69. 1848.

Fig. 5a-e

Árvores 5-10 m alt.; látex branco, ralo; ramos 3-6 mm diâm., castanho claro a castanho acinzentado, glabros. Estípulas 27-45 mm compr., caducas, verdes, castanho-esverdeadas a castanhoescuro quando secas, glabras em ambas as faces. Lâminas elípticas, 6-14 × 2-6 cm, coriáceas, ápice agudo a levemente acuminado, base aguda, glabras em ambas as faces, macias; $11-14$ pares de nervuras secundárias, proeminentes na face abaxial; pecíolos 1-3,5 cm compr., glabros a pubérulos, tricomas alvos, epiderme persistente, par de glândulas baselaminares. Sicônios aos pares, globosos, 4-14 $\mathrm{mm}$ diâm., lisos, glabros a pubérulos, tricomas alvos, macios, verdes, castanho-esverdeados quando secos, máculas alvo-esverdeadas; pedúnculos 1-5 mm compr., glabros; ostíolo plano a proeminente, circular, 1-3 mm diâm.; 5 orobrácteas externas; 2 epibrácteas, glabra em ambas as faces. Flores estaminadas pediceladas: 5 tépalas, livres, alvoamareladas, 2 estames; flores pistiladas: 5 tépalas, livres, alvo-amareladas, estigma liso, reto. Drupas ovais. Sementes alvo-amareladas.

Material selecionado: ESPÍRITO SANTO: Dores do Rio Preto, Três Estados, 12.X.2000, E.A. Costa 85 (RB). MINAS GERAIS: Carangola, centro da cidade, 29.VI.2000, L.S. Leoni \& J.B. Costa 4459 (GFJP). Chiador, UHE Simplício, 5.VII.2006, G. Pereira-Silva et al. 10839 (CEN, VIC). Muriaé, Usina Hidrelétrica Cachoeira Encoberta, 17.IV.1999, A. Salino \& P.O. Morais 4611 (BHCB, CESJ). Ponte Nova, 3.VIII.1995, G.E. Valente et al. 115 (SP, VIC). Viçosa, Duas Barras, 8.VIII.2007, P.P. Souza 189 (SP, VIC). RIO DE JANEIRO: Itaperuna, Fazenda Barra do Carangola, 18.III.2010, L.S. Leoni 7603 (GFJP). Itatiaia, às margens do rio Campo Belo, 1.II.2001, P.P. Souza 84 (RB). Resende, Avenida Presidente Kennedy, 16.II.2011, G. Pelissari et al. 201 (SP).

Ficus obtusiuscula poder ser confundida com $F$. adhatodifolia quando em estado vegetativo. Pertencem ao subgênero Pharmacosycea, no entanto F. obtusiuscula apresenta folhas 6-14 cm compr. e sicônios 4-14 mm diâm., enquanto $F$. adhatodifolia apresenta folhas 6,5-26,5 cm compr. e sicônios 15-27 mm diâm. Quando férteis $F$. obtusiuscula apresenta sicônios aos pares na axila das folhas e $F$. adhatodifolia os apresenta isolados na axila foliar.

Seus nomes populares são figueira, lombrigueira.

Tem como habitat a floresta estacional semidecidual submontana. Espécie frequentemente encontrada próximo a cursos d'água, em mata ciliar, sobre solo brejoso ou argilo-arenoso, desenvolvendo-se em pleno sol, em altitudes que variam de 190 a $770 \mathrm{~m}$. Apesar de possuir um número considerável de coletas na região, atuando como fonte de imigração de propágulos, não há registro de coletas em unidades de conservação, sendo encontrada em áreas sobre forte interferência antrópica. Espécie considerada "Vulnerável", VU devido a devido a qualidade e fragmentação da área de ocorrência da espécie, B1a,b(i,iii).

15. Ficus organensis (Miq.) Miq., Ann. Mus. Bot. Lugduno-Batavi 3: 299. 1867. Urostigma organense Miq., London J. Bot. 6: 542. 1847.

Fig. $5 f-j$

Árvores ou hemiepífitas 2-20 m alt.; látex branco, espesso; ramos 2-4 mm diâm., castanhoacinzentados, glabros a pubérulos, tricomas alvos. Estípulas 2-7 mm compr., caducas, esverdeadas, avermelhadas quando secas, face dorsal pubescente, tricomas alvos, face ventral glabra. Lâminas elípticas a ovais, 3,5-7,5 × 1,5-3,5 cm, cartáceas, ápice agudo, base aguda, glabras em ambas as faces, macias; $7-10$ pares de nervuras secundárias, planas na face abaxial; pecíolos $8-15 \mathrm{~mm}$ compr., glabros a pubescentes, tricomas alvos, epiderme persistente, glândula acropeciolar. Sicônios aos pares, globosos, 5-7 mm diâm., lisos, glabros, macios, verdes, castanho-claro a castanho-escuro quando secos, máculas vináceas; pedúnculos 1-4 mm compr., glabros; ostíolo plano, circular, 1-2 mm diâm.; 3 orobrácteas externas; 2 epibrácteas, face dorsal glabra, face ventral glabra a pubérulo, tricomas alvos. Flores estaminadas sésseis a pediceladas: 2-3 tépalas, livres ou adnatas na base, alvo-alaranjadas, 1 estame; flores pistiladas: 3 tépalas, livres ou adnatas na base, alvo-alaranjadas, estigma plumoso, decurrente ou reto. Drupas globosas. Sementes amareladas.

Material selecionado: MINAS GERAIS: Carangola, Serra da Grama, 12.II.1995, L.S. Leoni et al. 2784 (GFJP). Fervedouro, córrego Ararica, 19.V.2009, F. Marcolino \& R.S. Pereira 20 (GFJP). Pedra Dourada, VIII.1997, L.S. Leoni 3702 (GFJP). Rio Preto, Serra Negra, 10.IV.2004, K. Antunes et al. 78 (CESJ, SP). Viçosa, Bairro Belvedere, 14.XII.2010, G. Pelissari et al. 190 (SP). RIO DE JANEIRO: Itatiaia, estrada do Maromba, próximo à ponte do Maromba, 23.IV.2001, H.C. Lima et al. 5767 (RB, SP). SÃO PAULO: São José dos Campos, margens do Rio Paraíba do Sul, 22.VI.2002, MC. Assis et al. 1551 (HRCB, RB, SP).

Ficus organensis foi tratada por Berg \& Villavicencio (2004) como sinônimo de $F$. cestrifolia Schott, considerando esta última como espécie morfologicamente similar a $F$. hirsuta, 


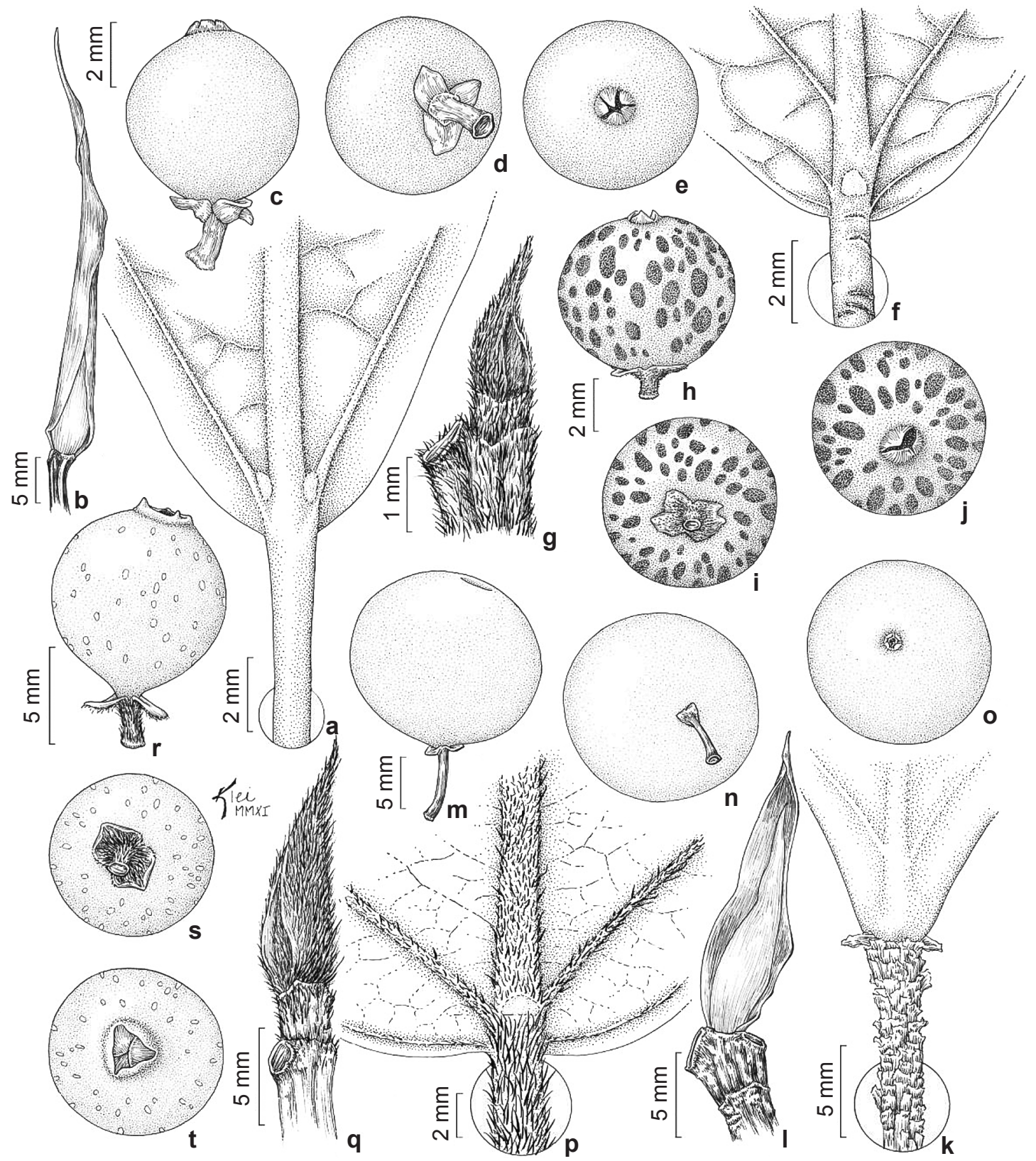

Figura 5 - a-e. F. obtusiuscula - a. base da lâmina foliar e par de glândulas baselaminares; b. estípula terminal no ramo; c. sicônio; d. vista basal do sicônio e epibrácteas; e. visão apical do sicônio, ostíolo e orobrácteas. f-j. F. organensis - f. base da lâmina foliar e glândula acropeciolar; g. estípula terminal no ramo e indumento; h. sicônio; i. visão basal do sicônio e epibrácteas; j. visão apical do sicônio, ostíolo e orobrácteas. k-o. F. pulchella - k. epiderme do pecíolo esfoliada; 1. estípula terminal no ramo; m. sicônio; n. visão basal do sicônio e epibrácteas; o. visão apical do sicônio, ostíolo e orobrácteas. p-t. F. trigona - p. base da lâmina foliar e glândula acropeciolar; q. estípula terminal no ramo; r. sicônio; s. visão basal do sicônio e epibrácteas; t. visão apical do sicônio, ostíolo e orobrácteas (a-e. Pelissari 201; f-j. Pelissari 190; k-o. Andrade 417; p-t. Souza 223).

Figure 5 - a-e. F. obtusiuscula - a. base of the leaf and a pair of baselaminar glands; b. terminal stipule on the twig; c. syconium; d. syconium basal view and epibracts; e. syconium apical view and orobracts. $\mathrm{f}-\mathrm{j}$. F. organensis $-\mathrm{f}$. base of the leaf and acropetiolar gland; g. terminal stipule on the twig and indument; h. syconium; i. syconium basal view and epibracts; j. syconium apical view and orobracts. k-o. F. pulchella - k. epidermis of the petiole flaking off; 1. terminal stipule on the twig; m. syconium; n. syconium basal view and epibracts; o. syconium apical view and orobracts. p-t. F. trigona - p. base of the leaf and acropetiolar gland; q. terminal stipule on the twig; r. syconium; s. syconium basal view and epibracts; t. syconium apical view and orobracts (a-e. Pelissari 201; f-j. Pelissari 190; k-o. Andrade 417; p-t. Souza 223). 
pelo fato de ambas apresentarem folhas pequenas. No entanto, $F$. cestrifolia apresenta número maior de nervuras secundárias e epiderme do pecíolo esfoliada, ao contrário de $F$. hirsuta que apresenta folhas com até seis nervuras secundárias e epiderme do pecíolo persistente (Berg \& Villavicencio 2004). Optou-se por considerar F. organensis e F. cestrifolia como espécies distintas, devido à presença de máculas vináceas, apontadas por Souza (2009) como importante carácter taxonômico, e epiderme do pecíolo persistente nos exemplares examinados da Mantiqueira.

Seus nomes populares são gameleira brava, mata pau.

Tem como habitat a floresta ombrófila densa e floresta estacional semidecidual submontana e montana. Ficus organensis pode ser encontrada em mata ciliar próximo a cursos d'água, em altitudes que variam de 430 a $1200 \mathrm{~m}$. Assim como na espécie descrita anteriormente, $F$. organensis não possui registros em unidades de conservação. Atua como fonte de imigração de propágulos na região, porém habita áreas com forte interferência antrópica. Espécie considerada "Vulnerável", VU devido a qualidade e fragmentação da área de ocorrência da espécie, B1a,b(i,iii).

16. Ficus pulchella Schott in Spreng., Syst. Veg., ed. 16. 4(2, App.): 410. 1827.

Fig. 5k-o

Árvores ca. $15 \mathrm{~m}$ alt.; látex branco, espesso; ramos ca. $5 \mathrm{~mm}$ diâm., castanhos, glabros. Estípulas ca. $1,7 \mathrm{~cm}$ compr., caducas, verdes, castanhoavermelhadas quando secas, glabras. Lâminas elípticas a oblongas, $8-13 \times 3,5-7 \mathrm{~cm}$, coriáceas, ápice agudo, base aguda, glabras em ambas as faces, macia; $15-18$ pares de nervuras secundárias, planas na face abaxial; pecíolos $1-1,5 \mathrm{~cm}$ compr., glabros, epiderme esfoliada, par de glândulas baselaminares. Sicônios solitários, globosos, 1,5-2 cm diâm., lisos, glabros, macios, verdes, castanhoescuro quando secos, máculas creme; pedúnculos ca. $7 \mathrm{~mm}$ compr., glabros; ostíolo plano, circular, ca. $1 \mathrm{~mm}$ diâm.; orobrácteas externas $5-7 ; 3$ epibrácteas, glabra em ambas as faces. Flores estaminadas pediceladas: 5 tépalas, livres, alvoamareladas, 2 estames; flores pistiladas: 5 tépalas, livres, alvo-amareladas, estigma liso, reto. Drupas ovais. Sementes amareladas.

Material selecionado: MINAS GERAIS: Caratinga, Estação Biológica de Caratinga, 6.IV.1990, L.V. Costa et al. (BHCB 22378); 20.X.1993, P.M. Andrade \& M.A. Lopes 417 (BHCB, SP). SÃO PAULO: Roseira, Fazenda do Aristide, 16.VIII.1995, S. Romaniuc Neto 1411 (SP).
Ficus pulchella é considerada por Berg \& Villavicencio (2004) espécie morfologicamente próxima a F. piresiana Vásq. Ávila \& C.C.Berg, descrita para a Amazônia venezuelana, no entanto as diferenciam pelo pecíolo $0,8-3(-3,5) \mathrm{cm}$ compr. e epiderme persistente em $F$. piresiana, enquanto $F$. pulchella apresenta pecíolo $0,3-1(-2,5) \mathrm{cm}$ compr. e epiderme esfoliada. Ao contrário de MendonçaSouza (2006), que não observou sementes nos espécimes de São Paulo, foi verificada a presença de sementes e galhas de vespas nos materiais provenientes da Mantiqueira, indicando provavelmente a presença da vespa polinizadora.

Seus nomes populares são figueira, caxinguba.

Seu habitat é remanescente de floresta ombrófila densa. Espécie encontrada entre 550 e $580 \mathrm{~m}$ de altitude. A espécie possui registro de coletas na Estação Biológica de Caratinga, que datam de aproximadamente 20 anos atrás. Espécie considerada "Próxima à Ameaçada", NT, pois não indivíduos próximos que atuem como fonte de imigração de propágulos.

\section{Ficus trigona L.f., Suppl. Pl.: 441. 1782.}

Fig. $5 \mathrm{p}-\mathrm{t}$

Árvores ou hemiepífitas 5-14 m alt.; látex branco a creme, espesso; ramos jovens $5-8 \mathrm{~mm}$ diâm., acinzentados a castanho-claros, pubescentes, tricomas alvo-amarelados. Estípulas 0,6-1,4 cm compr., castanho-amareladas quando secas, face ventral glabra, face dorsal pilosa a serícea, tricomas alvo-amarelados. Lâminas elípticas, ovadas ou obovadas, 6-14 × 3-7,5 cm, coriáceas, ápice agudo a acuminado, base arredondada a retusa; face adaxial glabra, face abaxial glabra a pilosa, tricomas alvoamarelados concentrados nas nervuras, macias; 4-8 pares de nervuras secundárias, proeminentes na face abaxial; pecíolos 1-2,5 cm compr., pubescentes, tricomas alvo-amarelados, epiderme persistente, glândula acropeciolar. Sicônios aos pares, globosos, 5-10 mm diâm., lisos, glabros a pubérulos, tricomas alvo-amarelados, macios, verdes, castanhos quando secos, máculas brancas; pedúnculos $2-4 \mathrm{~mm}$ compr., pubescentes a pilosos, tricomas alvo-amarelados; ostíolo crateriforme, triangular, 2-3 cm diâm.; 3 orobrácteas externas; 2 epibrácteas, face ventral glabra, face dorsal pubescente a serícea, tricomas alvo-amarelados a castanhos. Flores estaminadas pediceladas: 2-3 tépalas, livres, alvo-alaranjadas; 1 estame; flores pistiladas: 2-3 tépalas, livres, alvoalaranjadas; estigma plumoso, decurrente ou reto. Drupas globosas. Sementes amareladas a alaranjadas. 
Material selecionado: ESPÍRITO SANTO: Dores do Rio Preto, Três Estados, 12.X.2000, E.A. Costa 81 (RB). MINAS GERAIS: Carangola, Rio Carangola, 19.IX.1991, L.S. Leoni, 1644 (GFJP, GUA). Coronel Pacheco, Estação Experimental de Água Limpa, 28.VIII.1976, M.B. Ferreira 9579 (PAMG). Descoberto, Reserva Biológica da Represa do Grama, 21.IV.2001, R.M. Castro et al. 282 (BHCB, CESJ, GUA). Ponte Nova, 1.VII.1995, G.E. Valente et al. 67 (VIC, SP). Santa Rita do Jacutinga, 3.III.1987, L. Krieger (SP 304073). Tombos, Mata do Banco, 13.VII.2007, L.S. Leoni 6946 (GFJP). Viçosa, Sítio Bonsucesso, 17.I.2008, P.P. Souza 231 (SP, VIC).

Ficus trigona pode ser confundida com $F$. mariae quando em estado vegetativo, no entanto diferencia-se desta por apresentar ostíolo crateriforme triangular, enquanto $F$. mariae possui ostíolo circular. Apresenta inúmeros sinônimos, conforme Berg et al. (1984), Berg \& Simonis (2000) e Berg \& Villacencio (2004).

Seus nomes populares são figueira, mium.

Tem como habitat a floresta ombrófila densa e floresta estacional semidecidual. Ficus trigona é frequentemente encontrada próximo a cursos d'água, em áreas alteradas ou pastagens, em altitudes que variam de 270 a $720 \mathrm{~m}$. Apesar da maioria das coletas ser de áreas sujeitas à ação antrópica, possui registros recentes de coletas em unidades de conservação. Espécie considerada em “Menor Preocupaçao”, LC.

\section{Agradecimentos}

Ao $\mathrm{CNPq}$, a concessão de bolsa de mestrado à primeira autora. Aos curadores e funcionários dos herbários visitados. Aos colegas que acompanharam as viagens de coleta. À Dra. Inês Cordeiro a orientação e às Dras. Maria Candida Henrique Mamede e Roseli Buzanelli Torres, as sugestões prestadas. Ao Núcleo de Pesquisa Curadoria do Herbário SP e ao Programa de Pós-graduação em Biodiversidade Vegetal e Meio Ambiente do Instituto de Botânica de São Paulo. Ao ilustrador botânico Klei Souza.

\section{Referências}

Ash, A.W.; Ellis, B.; Hickey, L.J.; Johnson, K.R. \& Wilf, P. 1999. Manual of leaf architecture: morphological description and categorization of dicotyledons and net-veined monocotyledonous angiosperms. Smithsonian Institution, Washington D.C. 67p.

Berg, C.C. \& Carauta, J.P.P. 2002. New species of Ficus (Moraceae) from Brazil. Brittonia 54: 236-250.

Berg, C.C. \& Simonis, J.E. 2000. Moraceae. In: Riina, R. (ed.). Flora de Venezuela. Moraceae-Cecropiaceae. Fundación Instituto Botánico de Vezezuela, Caracas. Pp. 5-189.
Berg, C.C. \& Villavicencio, X. 2004. Taxonomic studies on Ficus (Moraceae) in the West Indies, extraAmazonian Brazil, and Bolivia. Ilicifolia 5: 1-177.

Berg, C.C.; Avila, M.V. \& Kooy, F. 1984. Ficus species of Brazilian Amazonia and the Guianas. Acta Amazonica Supl. 14: 159-194.

Berg, C.C.; Mello-Filho, L.E. \& Carauta, J.P.P. 1999. Ficus mariae (Moraceae), nova espécie SulAmericana. Bradea 8: 111-113.

Carauta, J.P.P. 1989. Ficus (Moraceae) no Brasil: Conservação e Taxonomia. Albertoa 2: 1-365.

Carauta, J.P.P. \& Diaz, B.E. 2002a. Figueiras no Brasil. Editora UFRJ, Rio de Janeiro. 208p.

Carauta, J.P.P. \& Diaz, B.E. 2002b. Ficus gomelleira Kunth (Moraceae): descrição latina do sicônio e comentários sobre o autor. Albertoa, sér. Urticineae (Urticales) 10: 67-68.

Carauta, J.P.P. \& Silva, R.R. 1996. Biota em risco de extinção. Albertoa 4: 61-76.

Casaretto, G. 1842. Novarum Stirpium Brasiliensium Decades. Decas 1: 15.

CETEC/Fundação Centro Tecnológico de Minas Gerais. 1983. Diagnóstico ambiental do estado de Minas Gerais. Vol. 1. CETEC, Belo Horizonte. 158p.

Chodat, R. \& Vischer, W. 1920. IX Urticiflores. In: Chodat, R. (ed.). La végétation du Paraguay. Bulletin de la Société Botanique de Genève, ser. 2 11: 226-258.

Colabardini, M.F.T. 2003. São João da Boa Vista: a paisagem geográfica da escarpa da Mantiqueira. Dissertação de Mestrado. Universidade Estadual Paulista, Rio Claro. 130p.

Dugand, A. 1942. Nuevas espécies colombianas del género Ficus. Caldasia 1: 25-74.

Fidalgo, O. \& Bononi, V.L.R. 1989. Técnicas de coleta, preservação e herborização de material botânico. Instituto de Botânica de São Paulo, São Paulo. 62p.

Garcia Junior, G. 2011. Caminhos da Mantiqueira. Empresa das Artes, São Paulo. 204p.

Hickey, M. \& King, C. 2000. The Cambridge illustrated glossary of botanical terms. Cambridge University Press, Cambridge. 208p.

IUCN Standards and Petitions Subcommittee. 2011. Guidelines for Using the IUCN Red List Categories and Criteria. Version 9.0. Disponível em <http:// www.iucnredlist.org/documents/RedListGuidelines. pdf. $>$. Acesso em 27 Out 2011.

Klink, C.A. \& Machado, R.B. 2005. A conservação do Cerrado brasileiro. Megadiversidade 1: 147-155.

Kunth, C.S. 1817. Urticeae. In: Humboldt, F.W.H.A. \& Bonpland, A.J.A. (eds.). Nova Genera et Species Plantarum. Vol. 2. Paris. Pp. 28-50.

Kunth, C.S. 1847. Enumeratio Synoptica Ficus specierum cum novarum tum congnitarum. Horti Regii Botanici Berolinenss. Index Seminum in Horto Botanico Berolinensi Anno 1846 Collectorum. Pp. 14-22. 
Kurtz, B.C. \& Araújo, D.S.D. 2000. Composição florística e estrutura do componente arbóreo de um trecho de Mata Atlântica na Estação Ecológica Estadual do Paraíso, Cachoeiras de Macacu, Rio de Janeiro, Brasil. Rodriguésia 51: 69-112.

Lawrence, G.H.M. 1951. Taxonomy of vascular plants. Macmillan, New York. 823p.

Lima, T.T. 2008. Bromeliaceae da Serra da Mantiqueira: distribuição geográfica e conservação. Dissertação de Mestrado. Instituto de Botânica de São Paulo, São Paulo. 341p.

Linnaeus, C. 1753. Species plantarum. Pp. 1059-1060.

Linnaeus f., C. 1782. Supplementum plantarum Systematis vegetabilium editionis decimae tertiae, Generum plantarum editiones sextae, et Specierum plantarum editionis secundae. Brunsvigae. Pp. 441-442.

Lopez-Vaamonde, C.; Wikstrom, N; Weiblen, G.D.; Rasplus, J.-Y.; Machado, C. \& Cook, J.M. 2009. Molecular dating and biogeography of fig-pollinating wasps. Molecular Phylogenetics and Evolution 52: 715-726.

Machado, A.F.P. \& Pederneiras, L.C. 2007. Moraceae do Espírito Santo, Brasil: lista de espécies. Albertoa, sér. Urticineae (Urticales) 31: 225-228.

Machado-Filho, L.; Ribeiro, M.W.; Gonzalez, S.R.; Schenini, C.A.; Santos-Neto, A.; Palmeira, R.C.B.; Pires, J.L.; Teixeira, W. \& Castro, H.E.F. 1983. Geologia. In: Projeto RADAMBRASIL. Geologia. Folhas SF:23/24. Rio de Janeiro/Vitória. Vol. 32. Rio de Janeiro. 779p.

Mcneill, J.; Barrie, F.R.; Burdet, H.M.; Demoulin, V.; Hawksworth, D.L.; Marhold, K.; Nicolson, D.H.; Prado, J.; Silva; P.C.; Skog, J.E.; Wiersema, J.H. \& Turland, N.J. 2006. International code of botanical nomenclature (Vienna Code). A.R.G. Gantner Verlag, Liechtenstein. 181p.

Mello-Fillho, L.E.; Neves, L.J.; Carauta, J.P.P. \& Diaz, B.E. 2001. Morfologia de certos sicônios de Ficus (Moraceae). Albertoa, sér. Urticineae (Urticales) 3: 17-18.

Mendonça-Souza, L.R. 2006. Ficus (Moraceae) no estado de São Paulo. Dissertação de Mestrado. Instituto de Botânica de São Paulo, São Paulo. 140p.

Miquel, F.A.W. 1847. Prodromus monogaphie Ficuum. London Journal of Botany 6: 514-588.

Miquel, F.A.W. 1853. Urticineae. In: C.F.P. Martius (ed.). Flora brasiliensis. Typographia Regia, Monachii, Lipsiae. Vol. 4, pt. 1. Pp. 78-106.

Miquel, F.A.W. 1867. Annotationes de Ficus speciebus. Annales Musei Botanici Lugduno-Batavi 3: 260-300.

Mittermeier, R.A.; Myers, N.; Gil, P.R. \& Mittermeier, C.G. 1999. Hotspots: earth's biologically richest and most endangered terrestrial ecoregions. Toppan Printing Co, Japão. 432p.

Mori, S.A.; Silva, L.A. M.; Lisboa, G. \& Coradin, L. 1989. Manual de manejo do herbário fanerogâmico. CEPLAC, Ilhéus. 104p.
Myers, N.; Mittermeier, R.A.; Mittermeier, C.G.; Fonseca, G.A.B. \& Kent, J. 2000. Biodiversity hotspots for conservation priorities. Nature 403: 853-858.

Pederneiras, L.C. 2011. Moraceae das restingas do estado do Rio de Janeiro. Rodriguésia 62: 77-92.

Radford, A.E.; Dickinson, W.C.; Massey, J.R. \& Bell, R. 1974. Vascular plant systematics. Harper \& Row, New York. 889p.

Romaniuc Neto, S.; Carauta, J.P.P.; Vianna Filho, M.D.M.; Pereira, R.A.S.; Ribeiro, J.E.L.S.; Machado, A.F.P.; Santos, A.; Pelissari, G. \& Pederneiras, L.C. 2012. Moraceae. In: Forzza, R.C. et al. (eds.). Lista de espécies da flora do Brasil. Jardim Botânico do Rio de Janeiro. Disponível em $<$ http:// floradobrasil.jbrj.gov.br/2012/FB010137>. Acesso em 7 Fev 2012.

Romaniuc Neto, S.; Mendonça-Souza, L.R.; Santos, A. \& São José, P.A. 2009. Moraceae. In: Melo, M.M.R.F.; Barros, F.; Chiea, S.A.C.; Kirizawa, M.; Mendaçolli, S.L. \& Wanderley, M.G.L. (eds.). Flora Fanerogâmica da Ilha do Cardoso. Vol.14. Instituto de Botânica de São Paulo, São Paulo. Pp. 59-86.

Rønsted, N.; Weiblen, G.D.; Cook, J.M.; Salamin, N.; Machado, C.A. \& Savolainen, V. 2005. 60 million years of codivergence in the fig-wasp symbiosis. Proceedings of The Royal Society Biological Sciences 272: 2593-2599.

Santos, O.A. 2010. Taxonomia e hipótese filogenética as seção Americana, subgênero Urostigma, gênero Ficus (Moraceae). Tese de Doutorado. Universidade Federal do Amazonas, Manaus. 102p.

Schott, H. 1827. Fasciculus plantarum brasiliensium. In: Sprengel, C.P.J. Systema Vegetabilium. Ed. 16. 4: 409-410.

Shanahan, M.; So, S.; Compton, S.G. \& Corlett, R. 2001. Fig-eating by vertebrate frugivores: a global review. Biological Reviews of the Cambridge Philosophical Society 76: 529-572.

Souza, P.P. 2009. Moraceae Gaudich. de Viçosa, Minas Gerais, Brasil: florística e anatomia foliar de Ficus mexiae Standl. Dissertação de Mestrado, Universidade Federal de Viçosa, Viçosa. 157p.

Standley, P.C. 1937. Studies of American Plants - VII. Publications of the Field Museum of Natural History. Botanical series. 17: 173.

Tabarelli, M; Pinto, L.P. Silva, J.M.C.; Hirota, M.M. \& Bedê, L.C. 2005. Desafios e oportunidades para a conservação da biodiversidade na Mata Atlântica. Megadiversidade 1: 132-138.

Thiers, B. 2012. [continuously updated]. Index Herbariorum: A global directory of public herbaria ans associated staff. New York Botanical Garden's Virtual Herbarium, Disponível em $<$ http:// sweetgum.nybg.org/ih/>. Acesso em 26 Out 2010.

Várzea, A. 1942. Relevo do Brasil. Revista Brasileira de Geografia 4: 97-130. 
Vazquez Avila, M.D. 1985. Ficus luschnathiana (Miq.) Miq., nombre correcto para Ficus monckii Hassler. Darwiniana 26: 381-382.

Vellozo, J.M.C. 1829. Florae Fluminensis: seu descriptionum plantarum praefectura Fluminensi sponte nascentium liber primus ad systema sexuale concinnatus / Augustissimae dominae nostrao per manus ill. Mi ae ex. Mi... Aloysii de Vasconcellos \& Souza Brasilae pro-regis quarti... ; sistit fr.
Josephus Marianus a Conceptione Velloza... 1790. Typographia nationali, Flumine Januario. Pp. 442. Vellozo, J.M.C. 1831. Florae Fluminensis Icones / nunc primo eduntur ... ; edidit Domnus Frater Antonius de Arrabida. Parisiis, v. 11, tab. 49-50.

Veloso, H.P., Rangel-Filho, A.L.R. \& Lima, J.C.A. 1991. Classificação da vegetação brasileira adaptada a um sistema universal. IBGE, Rio de Janeiro. 123p. 